\title{
Adamantane bisurea derivatives: anion binding in the solution and in the solid state
}

\author{
Vesna Blažek $^{\mathrm{a}}$, Krešimir Molčanov ${ }^{\mathrm{b}}$, Kata Mlinarić-Majerski ${ }^{\mathrm{a}}$, Biserka Kojić-Prodićb ${ }^{\text {, and }}$ \\ Nikola Basarića, \\ ${ }^{a}$ Department of Organic Chemistry and Biochemistry, Ruđer Bošković Institute, Bijenička cesta 54, 10000 \\ Zagreb, Croatia \\ ${ }^{\mathrm{b}}$ Department of Physical Chemistry, Ruđer Bošković Institute, Bijenička cesta 54, 10000 Zagreb, Croatia
}

\begin{abstract}
1,3-Bis-(3-arylureido)adamantane receptors, bearing phenyl $(\mathbf{5 , 6})$, 1-naphthyl $(\mathbf{7 , 8})$ and 9anthryl (9) fluorophore, were synthesized. Their ability for complexation with $\mathrm{F}^{-}, \mathrm{Cl}^{-}, \mathrm{Br}^{-}, \mathrm{OAc}^{-}$ , $\mathrm{NO}_{3}^{-} \mathrm{HSO}_{4}^{-}$, and $\mathrm{H}_{2} \mathrm{PO}_{4}^{-}$in solution was investigated by $\mathrm{UV}$-vis and fluorescence spectrophotometry. The binding was compared to that of 2-naphthyl bisurea derivatives with flexible spacers (bearing propylene or pentalene, 2 and 4) and rigid adamantane analogues (1 and 3). In solution, the receptors form stable complexes with all anions except with $\mathrm{NO}_{3}{ }^{-}$. The complexation ability in $\mathrm{CH}_{3} \mathrm{CN}$ correlates with the basicity of anion and the acidity of the urea $\mathrm{N}-\mathrm{H}$, whereas in DMSO the complexes stability variations are less pronounced. The X-ray structure of receptor $\mathbf{1}$ indicates that incorporation of the adamantane moiety preorganizes the receptor in a tweezer-like conformation for the optimal formation of hydrogen bonding network and high selectivity for $\mathrm{H}_{2} \mathrm{PO}_{4}^{-}$anion. Incorporation of the methylene spacers between the adamantane and the urea additionally increases stability of the complexes with anions. X-ray structural analysis was performed on the following complexes: $\mathbf{1} \cdot \mathrm{Bu}_{4} \mathrm{NH}_{2} \mathrm{PO}_{4}, \mathbf{3} \cdot \mathrm{Bu}_{4} \mathrm{NH}_{2} \mathrm{PO}_{4}$, 5. $\mathrm{Bu}_{4} \mathrm{NH}_{2} \mathrm{PO}_{4} \cdot 4 \mathrm{H}_{2} \mathrm{O}$, and 5. $\mathrm{Bu} 4 \mathrm{NOAc}_{3} \cdot 3 \mathrm{H}_{2} \mathrm{O}$. All $\mathrm{H}_{2} \mathrm{PO}_{4}{ }^{-}$complexes include extensive receptor ${ }^{\cdots} \mathrm{H}_{2} \mathrm{PO}_{4}{ }^{-}$hydrogen bonds, essential for the anion recognition, as well as $\mathrm{H}_{2} \mathrm{PO}_{4}{ }^{-}$ $\cdots \mathrm{H}_{2} \mathrm{PO}_{4}{ }^{-}$hydrogen bonds.
\end{abstract}

\section{Keywords:}

Adamantanes;

Anion receptors;

Fluorescence titration;

UV-vis titration;

Ureas;

$\mathrm{X}$-ray structural analysis

* Corresponding author. Tel.: +385-1-456-1141; fax: +385-1-468-0195; e-mail: nbasaric@irb.hr 


\section{Introduction}

Anions are key to many industrial and biological processes, playing important roles in health and environment. ${ }^{1}$ Therefore, in the past two decades, supramolecular chemistry of anions developed into a wide research field that has been extensively reviewed. ${ }^{2}$ The pioneering work concerned with discovering supramolecular synthons and basic priciples of binding anions ${ }^{3}$ lead to new advances in the field, involving rational design of receptors for anionic species, ${ }^{4}$ binding in more competitive aqueous media, ${ }^{5}$ transport through membranes, ${ }^{6}$ crystal engineering, ${ }^{7}$ or function of optical ${ }^{8}$ and electronic sensing devices ${ }^{9}$ and sensor arrays. ${ }^{10}$

De novo design of supramolecular hosts provides a powerful tool for generating and screening the artificial anionic receptors, which was accomplished by use of HostDesigner building software interfaced with molecular mechanics GMMX. ${ }^{11}$ The modelling-based design is primarily founded on H-bonding networks, using the most frequently urea and thiorea as synthons. ${ }^{12}$ The urea forms two H-bonds, controlling spatial orientation of the supramolecular building blocks in the complex molecular architectures. ${ }^{13}$ The de novo approach was applied to the bisurea derivatives to find optimal hydrocarbon skeletons for binding tetrahedral oxoanions. ${ }^{14}$ The rational design selected 25 structures for the optimal binding. However, new receptors ultimately have to be synthesized and their binding capabilities toward anions investigated.

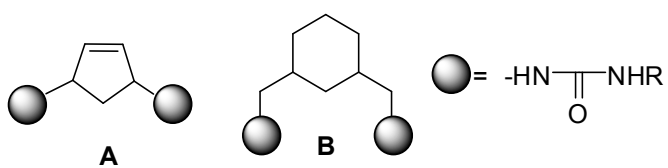

Recently we reported the synthesis and anion binding of a series of bisurea derivatives ${ }^{15}$ using modification of structural motifs $\mathbf{A}$ and $\mathbf{B}$ indicated by de novo design as good hosts for oxo-anions. ${ }^{14}$ The binding was investigated on a series of 2-naphthyl bisureas 1-4 by UV-vis, fluorescence, and NMR titrations. The structures were designed to probe the effect of rigidity on anion binding in solution. ${ }^{15}$ The urea moieties were separated by C-3 or C-5 methylene linkers which were flexible or rigid, due to an incorporated adamantane moiety. The rigid adamantane skeleton compared to the flexible receptors showed increased selectivity for $\mathrm{H}_{2} \mathrm{PO}_{4}{ }^{-}$. The binding of $\mathrm{H}_{2} \mathrm{PO}_{4}^{-}$was also investigated by microcalorimetry indicating that the enthalpic contribution to the overall complex stability was predominant. 

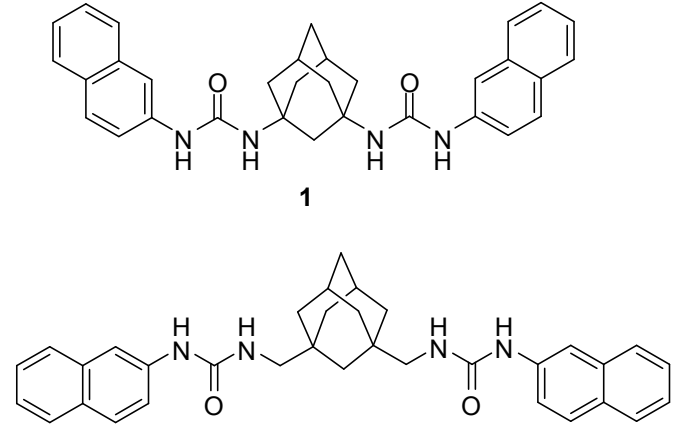
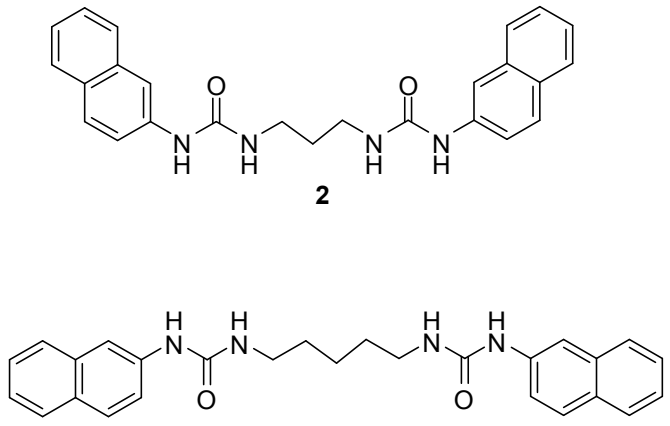

4

Herein we report on anion binding in solution, as well as in the solid state in a series of structurally related phenyl-, 1-naphthyl, and 9-anthryl adamantylidene bisureas 5-9. Bisurea receptors 5-9 are also characterized by C-3 or C-5 alkyl spacers between the ureas, wherein they are directly attached to the adamantane moiety, or separated by methylene spacers. The receptors 5 and 7 are very rigid where the urea groups have restricted conformational mobility, whereas in $\mathbf{6 , 8}$, and 9 methylene spacers between the adamantane and the ureas enable some conformational freedom. Rigid geometry can in principle preorganize receptors and enable formation of multiple H-bonds with anions, wherein the change of molecular conformation, and therefore the enthalpic penalty for the conformational change is minimal. On the other hand, H-bonding ability of the receptor can be strongly hindered due to rigid geometry. Furthermore, receptors 5-9 bear different aryl groups which should influence the $\mathrm{p} K_{\mathrm{a}}$ of the urea $\mathrm{NH}$, and therefore, the $\mathrm{H}$ bonding ability. The association constants with anions strongly depend on character of hydrogen bonding via N-H functionality. Furthermore, the dynamics of the complexation depend on the ability of receptors to form hydrogen bonds. However, changing the aromatic group does not only change the H-bonding ability due to electronic effects. The bulky aryl groups are expected to change the binding pattern due to steric effects. The priority of this work is to design optimal receptors capable of forming stable complexes with anions by multiple H-bonds. An important aspect which has to be taken into account in the design is also ability of some anions $\left(\mathrm{HSO}_{4}{ }^{-}\right.$and $\mathrm{H}_{2} \mathrm{PO}_{4}^{-}$) to form $\mathrm{H}$-bonds between two anions, or to undergo proton transfer. Therefore, it is required to optimize the molecular structure of the receptor, taking into account all abovementioned parameters, as well as to investigate the effect of solvent polarity to the H-bonding and complexation capability. In the study, anions were in the form of tetrabutylammonium salts. ${ }^{16}$ The anions of different size, basicity and geometry were used: spherical $\mathrm{F}^{-}, \mathrm{Cl}^{-}$, and $\mathrm{Br}^{-}$, Y-shaped $\mathrm{OAc}^{-}$, and $\mathrm{NO}_{3}{ }^{-}$and tetrahedral $\mathrm{HSO}_{4}{ }^{-}$, and $\mathrm{H}_{2} \mathrm{PO}_{4}{ }^{-}$. 


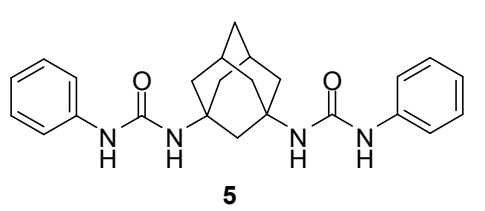<smiles>O=C(NCC12CC3CC(C1)C(CNC(=O)Nc1ccccc1)(C3)C2)Nc1ccccc1</smiles><smiles>O=C(Nc1cccc2ccccc12)NC1CC2CCC(C1)C2NC(=O)Nc1cccc2ccccc12</smiles><smiles>O=C(NCC12CC3CC(C1)CC(CNC(=O)Nc1cccc4ccccc14)(C3)C2)Nc1cccc2ccccc12</smiles><smiles></smiles>

\section{Results and discussion}

To probe the influence of an aromatic group attached to the urea, and the methylene spacers separating ureas from the rigid adamantanes to anion binding, receptors 5-9 were synthesized and their complexation with anions investigated.

\subsection{Synthesis}

Compounds 5-9 were prepared in moderate to good yields according to a modification of the published procedure ${ }^{17}$ from the corresponding carboxylic acids that were in situ transformed to isocyanates and reacted with amines. ${ }^{18,19}$ Bisurea 9 was prepared by another pathway, from anthracene-9-carboxylic acid and 1,3-bis(aminomethyl)adamantane. ${ }^{18}$ Spectroscopic and photophysical characterization of the urea derivatives were also reported. ${ }^{18,20}$

\subsection{Anion binding in the solution}

The presence of chromophoric groups in 5-9 enables the use of spectrophotometric methods for the determination of the association constants of the complexes with anions. Therefore, anion binding ability in solution was investigated by UV-vis, and fluorescence titrations. The titrations for $\mathbf{5}$ and $\mathbf{6}$ were performed only in $\mathrm{CH}_{3} \mathrm{CN}$ due to overlapping of the absorption of the compounds with DMSO at $<260 \mathrm{~nm}$. For $\mathbf{7}$ and $\mathbf{8}$, the titrations were carried out in both $\mathrm{CH}_{3} \mathrm{CN}$ and DMSO, whereas for 9 only measurements in DMSO were performed due to its low solubility in $\mathrm{CH}_{3} \mathrm{CN}$. Addition of anions to the solution of the receptors generally induced bathochromic and hyperchromic changes in the spectra. The observed changes are in accordance with the increase of electron density on the aromatic substituents and an increased 
negative charge at the urea nitrogen upon formation of the H-bonds with anions. ${ }^{21}$ Dependences of the absorption spectra on anion concentrations were processed by multivariate nonlinear regression analysis by use of SPECFIT program ${ }^{22}$ to determine the complex stoichiometries and the association constants (see Supporting info). The estimated binding constants are listed in Table 1. The addition of $\mathrm{NO}_{3}{ }^{-}$caused only small changes in the UV-vis spectra precluding further analyses and estimation of the association constants.

Addition of $\mathrm{Bu}_{4} \mathrm{NF}$ to the solution of bisureas 5-9 resulted in pronounced changes in their UV-vis spectra, in accordance with the formation of complexes with $\mathrm{F}^{-}$(Figs. 1 and 2). It was shown that 1 and $\mathbf{3}$ form 1:1 complexes with $\mathrm{F}^{-}$in the $\mathrm{CH}_{3} \mathrm{CN}$ solution, whereas in DMSO 1-4 form 1:1 and 1:2 complexes (receptor:anion). ${ }^{15}$ Similarly, receptors 5 and $\mathbf{6}$ form only 1:1 complexes in $\mathrm{CH}_{3} \mathrm{CN}$. On the other hand, processing of the UV-vis curves for 7-9 was best fitted to a model involving formation of 1:1 and/or 1:2 complexes. Generally, the association constants of the 1:1 complexes in $\mathrm{CH}_{3} \mathrm{CN}$ are in the range $10^{3}-10^{6} \mathrm{M}^{-1}$, increasing up to an order of magnitude with receptors bearing methylene spacers between the urea moieties and the rigid adamantane. Change of the phenyl substituent in the receptors, by 1-naphthyl significantly changed their binding behaviour (Figs. 1 and 2). For 5 and $\mathbf{6}$, addition of $\mathrm{F}^{-}$resulted in a bathochromic shift of the maximum in the UV-vis spectra for $\approx 15 \mathrm{~nm}$, whereas for 1-naphthyl the shift was larger $\approx 30 \mathrm{~nm}$, suggesting that $\mathrm{F}^{-}$perturbs more strongly the electronic excitation of the 1-naphthylurea, than the phenylurea. The finding can be rationalized by stronger acidity of 1-naphthylamine compared to aniline (vide infra) and formation of more negative charge on the urea $\mathrm{N}$ atom on complexation. The stronger acidity correlates with higher association constans of the corresponding 1:1 complexes in $\mathrm{CH}_{3} \mathrm{CN}$ for $\mathbf{7}$ and $\mathbf{8}$ (compared to $\mathbf{5}$ and $\mathbf{6}$, respectively), being two orders of magniture higher.

Table 1. Cumulative stability constants of the complexes with anions determined by UV-vis titrations $\left[\log \left(\beta_{11} / \mathrm{M}^{-1}\right)\right]$ or $\left[\log \left(\beta_{12} / \mathrm{M}^{-2}\right)\right]^{\mathrm{a}}$

\begin{tabular}{|c|c|c|c|c|c|}
\hline $\begin{array}{l}\text { Anion/Re } \\
\text { c. }\end{array}$ & $5^{\mathrm{b}}$ & $6^{\mathrm{b}}$ & $7^{\mathrm{b}, \mathrm{c}}$ & $\mathbf{8}^{\mathrm{b}, \mathrm{c}}$ & $9^{c}$ \\
\hline $\mathrm{F}^{-}$ & $\begin{array}{l}3.30 \pm 0.04(1 \\
: 1)\end{array}$ & $4.11 \pm 0.04(1: 1)$ & $\begin{array}{l}5.3 \pm 0.3(1: 1)^{\mathrm{b}} \\
8.9 \pm 0.3(1: 2)^{\mathrm{b}} \\
6.46 \pm 0.04(1: 2)^{\mathrm{c}}\end{array}$ & $\begin{array}{l}6.6 \pm 0.3(1: 1)^{b} \\
10.8 \pm 0.3(1: 2) \\
b \\
6.43 \pm 0.05(1: 2) \\
c\end{array}$ & $\begin{array}{l}6.35 \pm 0.04(1: 2 \\
)\end{array}$ \\
\hline $\mathrm{Cl}^{-}$ & $\begin{array}{l}2.72 \pm 0.02 \\
(1: 1)\end{array}$ & $3.71 \pm 0.04(1: 1)$ & $3.05 \pm 0.02(1: 1)^{\mathrm{b}}$ & $3.32 \pm 0.01(1: 1)^{b}$ & $<2^{\mathrm{e}}$ \\
\hline $\mathrm{Br}^{-}$ & $-\mathrm{e}$ & $3.04 \pm 0.03(1: 1)$ & $2.54 \pm 0.06(1: 1)^{\mathrm{b}}$ & $\begin{array}{l}2.89 \pm 0.01(1: 1) \\
\mathrm{b}\end{array}$ & $-c, d$ \\
\hline
\end{tabular}


Blažek, V.; Molčanov, K.; Mlinarić-Majerski, K.; Kojić-Prodić, B.; Basarić, N. Adamantane bisurea derivatives: anion binding in the solution and in the solid state. Tetrahedron. 2013, 69, 517-526. DOI: 10.1016/j.tet.2012.11.030 - Accepted Version

\begin{tabular}{|c|c|c|c|c|c|}
\hline \multirow[t]{2}{*}{$\mathrm{OAc}^{-}$} & $\begin{array}{l}3.78 \pm 0.02 \\
(1: 1)\end{array}$ & $5.09 \pm 0.04(1: 1)$ & $3.26 \pm 0.04(1: 1)^{\mathrm{b}}$ & $\begin{array}{l}4.94 \pm \\
0.04(1: 1)^{b}\end{array}$ & $\begin{array}{l}3.46 \pm 0.09(1: 1 \\
)\end{array}$ \\
\hline & & & $3.8 \pm 0.2(1: 1)^{\mathrm{c}}$ & $3.2 \pm 0.2(1: 1)^{\mathrm{c}}$ & \\
\hline $\mathrm{HSO}_{4}^{-}$ & $\begin{array}{l}1.45 \pm 0.08 \\
(1: 1)\end{array}$ & $2.72 \pm 0.05(1: 1)$ & $1.82 \pm 0.08(1: 1)^{\mathrm{b}}$ & $2.51 \pm 0.03(1: 1)^{\mathrm{b}}$ & $-c, d$ \\
\hline \multirow[t]{4}{*}{$\mathrm{H}_{2} \mathrm{PO}_{4}^{-}$} & $\begin{array}{l}9.38 \pm 0.01 \\
(1: 2)\end{array}$ & $5.11 \pm 0.03(1: 1)$ & $5.1 \pm 0.2(1: 1)^{\mathrm{b}}$ & $5.8 \pm 0.3(1: 1)^{\mathrm{b}}$ & $\begin{array}{l}3.73 \pm \\
0.08(1: 1)\end{array}$ \\
\hline & & $7.8 \pm 0.1(1: 2)$ & $9.1 \pm 0.1(1: 2)^{\mathrm{b}}$ & $10.7 \pm 0.3(1: 2)^{\mathrm{b}}$ & \\
\hline & & & $2.61 \pm 0.07(1: 1)^{\mathrm{c}}$ & $4.25 \pm 0.07(1: 1)^{\mathrm{c}}$ & $\begin{array}{l}6.57 \pm \\
0.07(1: 2)\end{array}$ \\
\hline & & & $5.20 \pm 0.09(1: 2)^{\mathrm{c}}$ & $7.81 \pm 0.09(1: 2)^{\mathrm{c}}$ & \\
\hline
\end{tabular}

${ }^{\mathrm{a}}$ The anion is added in the form of tetrabutylammonium salt. Stoichiometries of the complexes are indicated in the parentheses (receptor:anion).

${ }^{\mathrm{b}}$ Titration performed in $\mathrm{CH}_{3} \mathrm{CN}$.

${ }^{c}$ Titration performed in DMSO.

${ }^{\mathrm{d}}$ No binding observed.

e Very small changes were observed in the UV-vis spectra and the data could not be used to estimate the association constants.
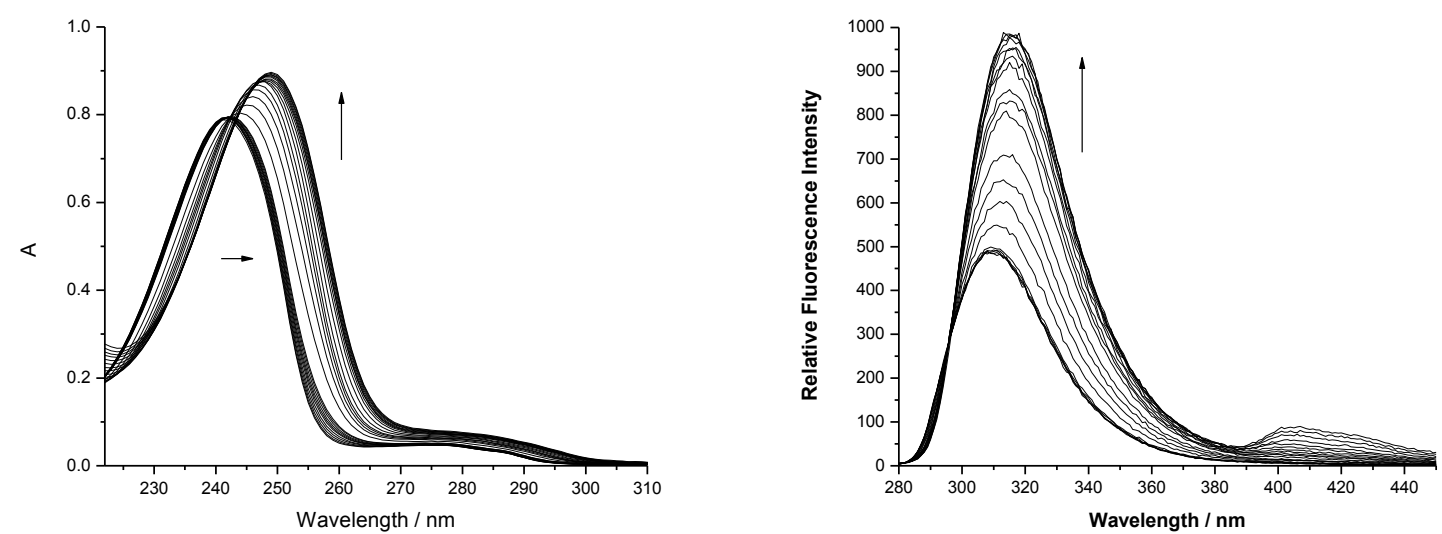

Fig. 1. Uv-vis (left) and fluorescence titration (right, $\lambda_{\mathrm{ex}}=242 \mathrm{~nm}$ ) of 5 with $\mathrm{F}^{-}$in $\mathrm{CH}_{3} \mathrm{CN}$. The bottom curve corresponds to the solution of $\mathbf{5}$, whereas the curves from bottom to top correspond to the solutions with increasing concentration of $\mathrm{Bu}_{4} \mathrm{NF}$. 

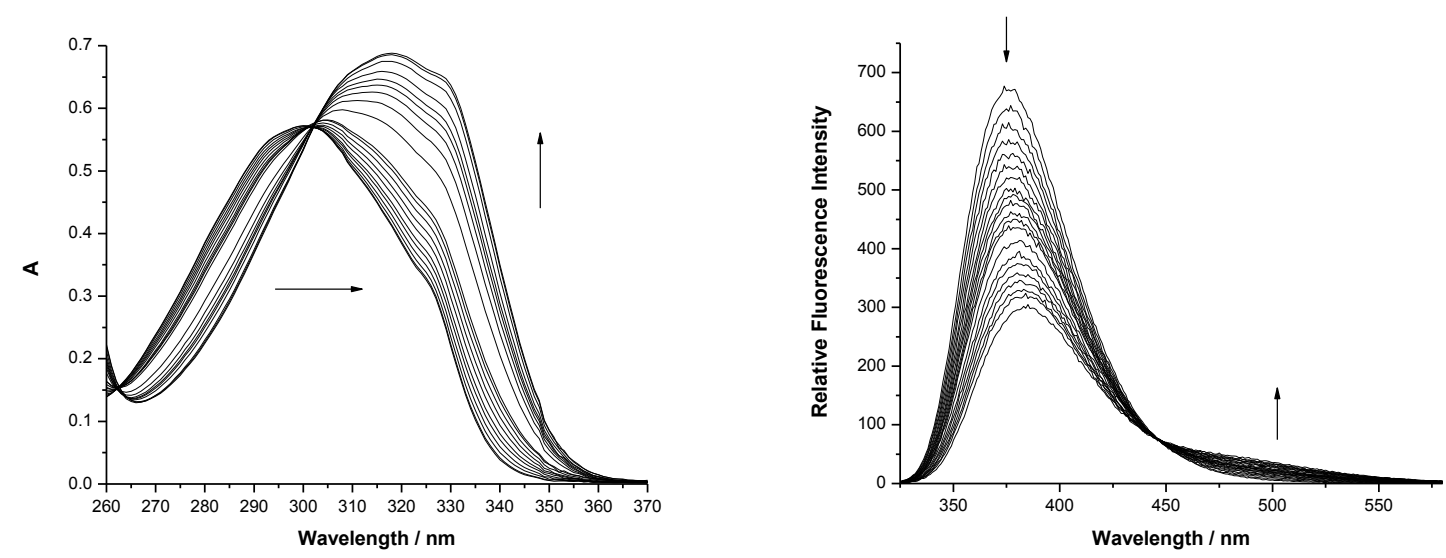

Fig. 2. Uv-vis (left) and fluorescence (right, $\lambda_{\mathrm{ex}}=300 \mathrm{~nm}$ ) titration of 7 with $\mathrm{F}^{-}$in $\mathrm{CH}_{3} \mathrm{CN}$. In the UV-vis spectra the bottom curve corresponds to the solution of 7, whereas the curves from bottom to top correspond to the solutions with increasing concentration of $\mathrm{Bu}_{4} \mathrm{NF}$. In the fluorescence spectra the top curve corresponds to the solution of 7 , whereas the curves from top to bottom correspond to the solutions with increasing concentration of $\mathrm{Bu}_{4} \mathrm{NF}$.

Large bathochromic shifts of the maxima for the receptors 7 and $\mathbf{8}$ provide their potential applications as ratiometric indicators for $\mathrm{F}^{-}$. Furthermore, 1-naphthyl derivatives in $\mathrm{CH}_{3} \mathrm{CN}$ form 1:1 and 1:2 complexes, whereas in DMSO 7-9 formed only 1:2 complexes with similar values of the association constants. The similar association constants in DMSO probably reflect large influence of the solvent to anion and receptors solvation, thus diminishing smaller differences in the acidity and binding capabilities of receptors 7-9.

Receptors 5 and 6 compared to 7-9 show unexpectedly different binding stoichiometries with $\mathrm{F}^{-}$and different spectral changes. We anticipate that the acidity of the NH decreases in the sequence, 9-aminoanthracene, 1-aminonaphthalene, 2-aminonaphthalene and aniline. Furthemore, it is well known that $\mathrm{F}^{-}$is a basic anion that can induce deprotonation of the acidic urea or pyrrole $\mathrm{NH}^{23}$ Indication of the formation of $1: 1$, as well as $1: 2$ stoichiometry of the complexes with $\mathrm{F}^{-}$can principally be due to formation of a complex with two anions, or due to deprotonation and giving $\mathrm{HF}_{2}{ }^{-23}$ Therefore, it is plausible to assume that 7-9 undergo deprotonation in the presence of excess of $\mathrm{F}^{-}$. However, deprotonation is usually visualized by a large spectral change with appearance of a new band at longer wavelengths in the UV-vis spectra, which was not observed for 7-9. The finding suggests that deprotonation probably does not take place, but receptors 7-9 form complexes with the two $\mathrm{F}^{-}$. Consequently, increase of the urea $\mathrm{NH}$ acidity increases H-bonding ability, stability of the corresponding complexes, and enables formation of the 1:2 stoichiometries. H-bond can actually be considered as a frozen state of 
proton transfer from the donor (acid) to acceptor (base), with more advanced proton transfer leading to stronger interactions. ${ }^{24}$ A partial proton transfer in the $\mathrm{H}$-bonding complexes with $\mathrm{F}^{-}$ and amidoureas in DMSO was recently reported by Gunnlaugsson. ${ }^{25}$

To further investigate the complexation of receptors with $\mathrm{F}^{-}$, in addition to the UV-vis, fluorescence titrations were performed for 1, 3 and 5-9 (Figs. 1 and 2, and Supporting info.). The fluorescence spectra obtained by titrations were processed by multivariate nonlinear regression analysis giving the association constants and the stoichiometries of the corresponding complexes. Generally, the association constants (Table 2) do not agree very well with those obtained by $\mathrm{UV}$-vis titrations, except for $\mathbf{1}$, and $\mathbf{3}$ in $\mathrm{CH}_{3} \mathrm{CN}$, and $\mathbf{5}$ and $\mathbf{6}$. Moreover, the differences observed by fluorescence titrations for receptors 5 and 6, compared to 1, 3 and 7-9 are even larger than in the UV-vis titrations. Whereas addition of $\mathrm{Bu}_{4} \mathrm{NF}$ to the $\mathrm{CH}_{3} \mathrm{CN}$ solution of 5 and 6 increases fluorescence, it leads to fluorescence quenching for 7-9. Furthermore, on addition of a large excess of $\mathrm{F}^{-}$in the fluorescence spectra of 7-9 a new band at longer wavelengths was observed. Obviously, there should be a different mechanism in the binding of $\mathrm{F}^{-}$between phenyl, and 2-naphthyl compared to1-naphthyl and anthryl derivatives. The new band at longer wavelengths in the fluorescence spectra was tentatively assigned to the fluorescence of the deprotonated form of the receptor formed in the excited state. It is known that 1 aminonaphthalene (similar to 1-naphthol) becomes more acidic in $\mathrm{S}_{1}\left(\mathrm{p} K_{\mathrm{a}} *=13.5\right)^{26}$ which can lead to an adiabatic deprotonation in the presence of a strong base such as $\mathrm{F}^{-}$. Therefore, estimated 1:2 binding constants by fluorescence titrations for 7-9 probably correspond to cumulative constants involving more equilibria, complexation, proton transfer, and association of the species after the proton transfer. In DMSO, proton transfer in both, ground and excited state becomes more probable. However, due to solvent competition to binding with urea and strong solvation of the anions, the association constants of the complexes with anions are lower.

Table 2. Cumulative stability constants of the complexes with $\mathrm{F}^{-}$determined by fluorescence titrations $\left[\log \left(\beta_{11} / \mathrm{M}^{-1}\right)\right]$ or $[\log$ $\left.\left(\beta_{12} / \mathrm{M}^{-2}\right)\right]^{\mathrm{a}}$

\begin{tabular}{lcl}
\hline Receptor & \multicolumn{1}{c}{$\mathrm{CH}_{3} \mathrm{CN}$} & \multicolumn{1}{c}{ DMSO } \\
\hline $\mathbf{1}$ & $7.79 \pm 0.05(1: 2)$ & $4.6 \pm 0.2(1: 1)$ \\
& & $7.0 \pm 0.2(1: 2)$ \\
$\mathbf{3}$ & $4.44 \pm 0.03(1: 1)$ & $4.27 \pm 0.08(1: 1)$ \\
& & $6.8 \pm 0.2(1: 2)$ \\
$\mathbf{5}$ & $3.35 \pm 0.05(1: 1)$ & -
\end{tabular}




\begin{tabular}{|c|c|c|}
\hline 6 & $4.49 \pm 0.08(1: 1)$ & - \\
\hline 7 & $7.46 \pm 0.04(1: 2)$ & $6.84 \pm 0.09(1: 2)$ \\
\hline \multirow[t]{2}{*}{8} & $4.72 \pm 0.05(1: 1)$ & $6.73 \pm 0.09(1: 2)$ \\
\hline & $7.7 \pm 0.2(1: 2)$ & \\
\hline 9 & - & $5.87 \pm 0.04(1: 2)$ \\
\hline
\end{tabular}

To verify if binding of $\mathrm{F}^{-}$leads to deprotonation, NMR titrations were performed for receptors 5 and 7. Due to low solubility of receptors in acetonitrile, the titrations were performed in $d_{6}$-DMSO (for the spectra see Supporting info. Figs. S107-S110). An addition of $\mathrm{Bu}_{4} \mathrm{NF}$ to the solution gave rise to the most pronounced shifting of the urea $\mathrm{NH}$-signals to lower magnetic field. On addition of two equivalents of $\mathrm{F}^{-}$the urea NH signals of the receptor 5 shifted from 6.0 and $8.2 \mathrm{ppm}$ to 7.6 and $10.4 \mathrm{ppm}$, respectively, whereas aromatic $\mathrm{C}-\mathrm{H}$ signals exhibited a small upfield shift of $0.1 \mathrm{ppm}$. The ${ }^{1} \mathrm{H}$ NMR spectral shifts strongly indicate that $\mathrm{F}^{-}$ binds to the both urea $\mathrm{NH}$, forming a stronger $\mathrm{H}$-bond with the more acidic $\mathrm{NH}$, the one attached to the aromatic moiety. The complexation results in the increase of the negative charge on the $\mathrm{N}$-atom, and therefore, signals of the aromatic C-H shift to the higher magnetic field. Fitting of the dependence of the chemical shift corresponding to the $\mathrm{N}-\mathrm{H}$ atoms for $\mathbf{5}$ on $\mathrm{Bu}_{4} \mathrm{NF}$ concentration by EQNMR reveals formation of the complexes with $\beta_{11} \approx 10^{4} \mathrm{M}^{-1}$ and $\beta_{12} \approx 10^{7}$ $\mathrm{M}^{-2}$. Since addition of the huge excess of $\mathrm{F}^{-}$did not result in the disappearance of the N-H signals, the finding strongly indicates that the urea moieties in the receptors $\mathbf{5}$ and $\mathbf{7}$ are not acidic enough to be deprotonated in the ground state by $\mathrm{F}^{-}$(at least not in the concentration range typical for the NMR experiments, $10^{-3} \mathrm{M}$ ).

The binding of spherical anions, $\mathrm{Cl}^{-}$and $\mathrm{Br}^{-}$, which are less basic than $\mathrm{F}^{-}$, induced smaller changes in the UV-vis spectra of the receptors 5-9. The binding was accomplished in 1:1 stoichiometry only, and the values of the association constants of the complexes are decreasing from $\mathrm{F}^{-}$to $\mathrm{Br}^{-}$. Similarly to the observations with $\mathrm{F}^{-}$, use of methylene spacers between the urea moieties and adamantane increased the binding abilities of $\mathrm{Cl}^{-}$, enhancing the corresponding association constants about two times for the 1-naphthyl and ten times for the phenyl derivative. Probably, larger spherical anions can better fit into a cleft between two urea arms than small $\mathrm{F}^{-}$and therefore, binding by $\mathrm{H}$-bonds from both urea arms may be possible. 
Contrary to the formation of complexes with $\mathrm{F}^{-}$, binding of larger anions $\mathrm{Cl}^{-}$and $\mathrm{Br}^{-}$was accomplished with larger association constants for the phenyl derivatives than for the 1naphthyl and anthryl. Increase of the size of the aromatic skeleton most likely results in the increase of the steric hindrance for the complexation, thus decreasing the binding capability for larger anions.

The urea functional group is complementary to acetate, capable of forming two coplanar H-bonds. ${ }^{27}$ However, binding of acetate or benzoate can be accomplished by significantly higher association constants by a chelate effect of two urea grups forming four H-bonds. ${ }^{28}$ Therefore, binding of $\mathrm{OAc}^{-}$is optimal for receptors $\mathbf{6}$ and $\mathbf{8}$ with methylene spacers between the urea moiety and the adamantane, making feasible multiple H-bonds with anions. Indeed, the measured association constant with $\mathrm{OAc}^{-}$for $\mathbf{6}$ in $\mathrm{CH}_{3} \mathrm{CN}$ is twenty times larger than for $\mathbf{5}$, and fifty times larger for $\mathbf{8}$ than for 7 . In addition, the measured association constants for $\mathrm{OAc}^{-}$ with $\mathbf{6}$ and $\mathbf{8}$ is higher than for the similar bidentate urea ligands on $m$-phenylene ${ }^{29}$ anthracene, ${ }^{30}$ or norbornene, ${ }^{31}$ or comparable to binding by $o$-phenylenediamine ${ }^{32}$ or xanthene ${ }^{33}$ bisurea derivatives. On the contrary to the $\mathrm{CH}_{3} \mathrm{CN}$ solutions, similar association constants with $\mathrm{OAc}^{-}$ were determined for 7-9 in DMSO, suggesting strong solvation of the receptors and anion by DMSO, leading to smaller changes in the binding capability imposed by the modification of the molecular structure and acidity of the receptors.

The investigated receptors formed complexes with $\mathrm{HSO}_{4}^{-}$with relatively small association constants in $\mathrm{CH}_{3} \mathrm{CN}$, whereas in DMSO no binding was observed. Similar to the spherical anions, binding of tetrahedral $\mathrm{HSO}_{4}^{-}$was also accomplished more easily with receptors having methylene spacers between the urea moiety and the bulky adamantane. Thus, the association constant for $\mathrm{HSO}_{4}{ }^{-}$and $\mathbf{6}$ is nineteen times larger than for $\mathbf{5}$, and five times larger for 8 than for 7. It is known that efficient binding of $\mathrm{HSO}_{4}^{-}$can be accomplished through multiple H-bonds (five or more) due to strong solvation of the anion. ${ }^{34}$ To optimize the use of donor/acceptor ratio, both urea moieties of the receptor probably participate in the binding of this tetrahedral anion. Therefore, the receptors with methylene spacers between the urea moieties and bulky adamantane are sterically optimal scaffolds for hydrogen bonding with $\mathrm{HSO}_{4}^{-}$.

Adamantane bisurea derivatives $\mathbf{1}$ and $\mathbf{3}$ are particularly selective for binding $\mathrm{H}_{2} \mathrm{PO}_{4}^{-}$, forming 1:2 complexes driven by the favorable enthalpic contribution. ${ }^{15}$ Similarly, receptors 59 formed very stable complexes with $\mathrm{H}_{2} \mathrm{PO}_{4}{ }^{-}$in the stoichiometries 1:1 and 1:2 characterized 
by association constants reaching $5 \times 10^{10} \mathrm{M}^{-2}$ for $\mathbf{8}$. These are among the highest association constants ever reported for binding $\mathrm{H}_{2} \mathrm{PO}_{4}{ }^{-}$. However, one should be aware that UV-vis spectrometry is not the appropriate method for the determination of high association constants. Strong binding correlates with the relatively large increase of the negative charge on the Natom of the urea due to formation of strong $\mathrm{H}$-bonds with anion. This effect is manifested in the UV-vis spectra. Addition of $\mathrm{H}_{2} \mathrm{PO}_{4}^{-}$to the $\mathrm{CH}_{3} \mathrm{CN}$ solution of 5 and $\mathbf{6}$ induced $15 \mathrm{~nm}$ bathochromic shifts, whereas in the solutions of $\mathbf{7}$ and $\mathbf{8}$, shifts of $20 \mathrm{~nm}$ were observed (Fig. 3). Titration in DMSO caused less pronounced changes in the UV-vis spectra. This finding correlates with several orders of magnitude smaller values of the association constants due to competition of DMSO for solvation of anions. However, the value of the association constants for 5-9 cannot be directly correlated with molecular structure. Namely, 6 forms less stable complexes with $\mathrm{H}_{2} \mathrm{PO}_{4}{ }^{-}$than $\mathbf{5}$, whereas more flexible receptor 8 forms more stable complexes than the rigid receptor 7. Binding of $\mathrm{H}_{2} \mathrm{PO}_{4}{ }^{-}$in the stoichiometry $1: 2$ has already been reported for bisurea derivatives. ${ }^{29,35}$ Later, it was shown that stoichiometry 1:2 can be due to the formation of two $^{36}$ or 3 intermolecular $\mathrm{H}$-bonds between two $\mathrm{H}_{2} \mathrm{PO}_{4}{ }^{-}$anions. ${ }^{37}$ This cooperative effect additionally stabilizes 1:2 stoichiometries rendering them more stable than the corresponding 1:2 complexes with other anions where H-bonds between anions are not possible. Relatively large bathochromic shifts in the UV-vis spectra of $\mathbf{7}$ and $\mathbf{8}$ and large association constants enable potential use of these receptors as ratiometric chromogenic $\mathrm{H}_{2} \mathrm{PO}_{4}{ }^{-}$ sensors.
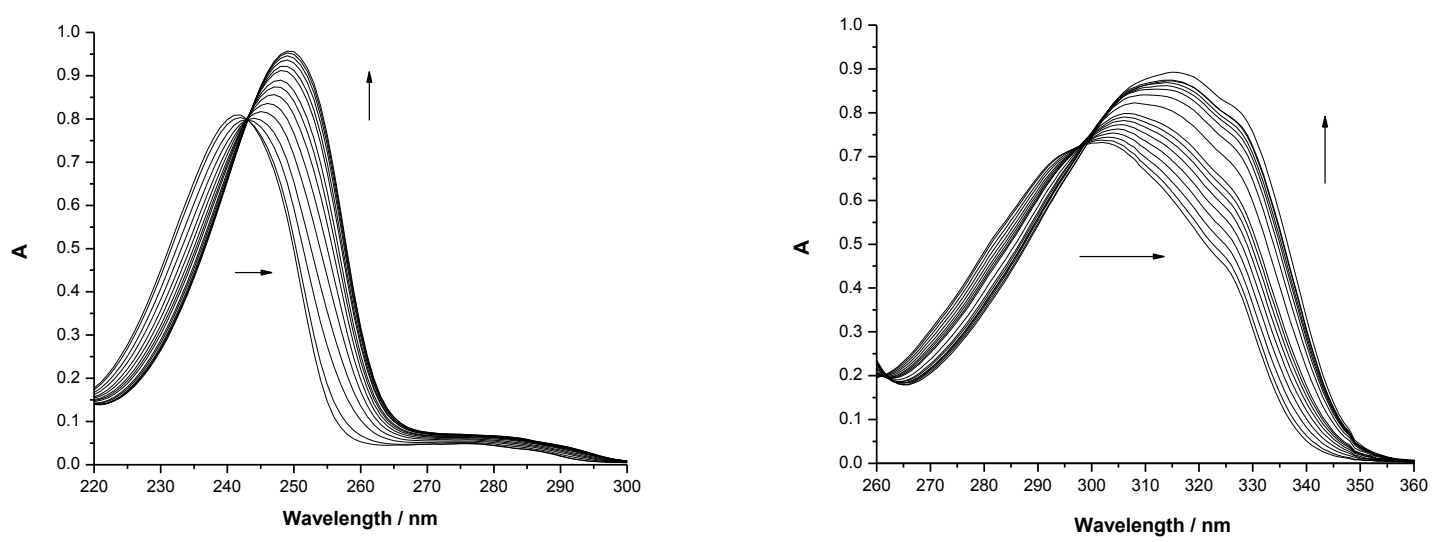

Fig. 3. Uv-vis and titration of 5 (left) and 7 (right) with $\mathrm{H}_{2} \mathrm{PO}_{4}{ }^{-}$in $\mathrm{CH}_{3} \mathrm{CN}$. The bottom curve corresponds to the solution of receptor, whereas the curves from bottom to top correspond to the solutions with increasing concentration of $\mathrm{Bu}_{4} \mathrm{NH}_{2} \mathrm{PO}_{4}$. 

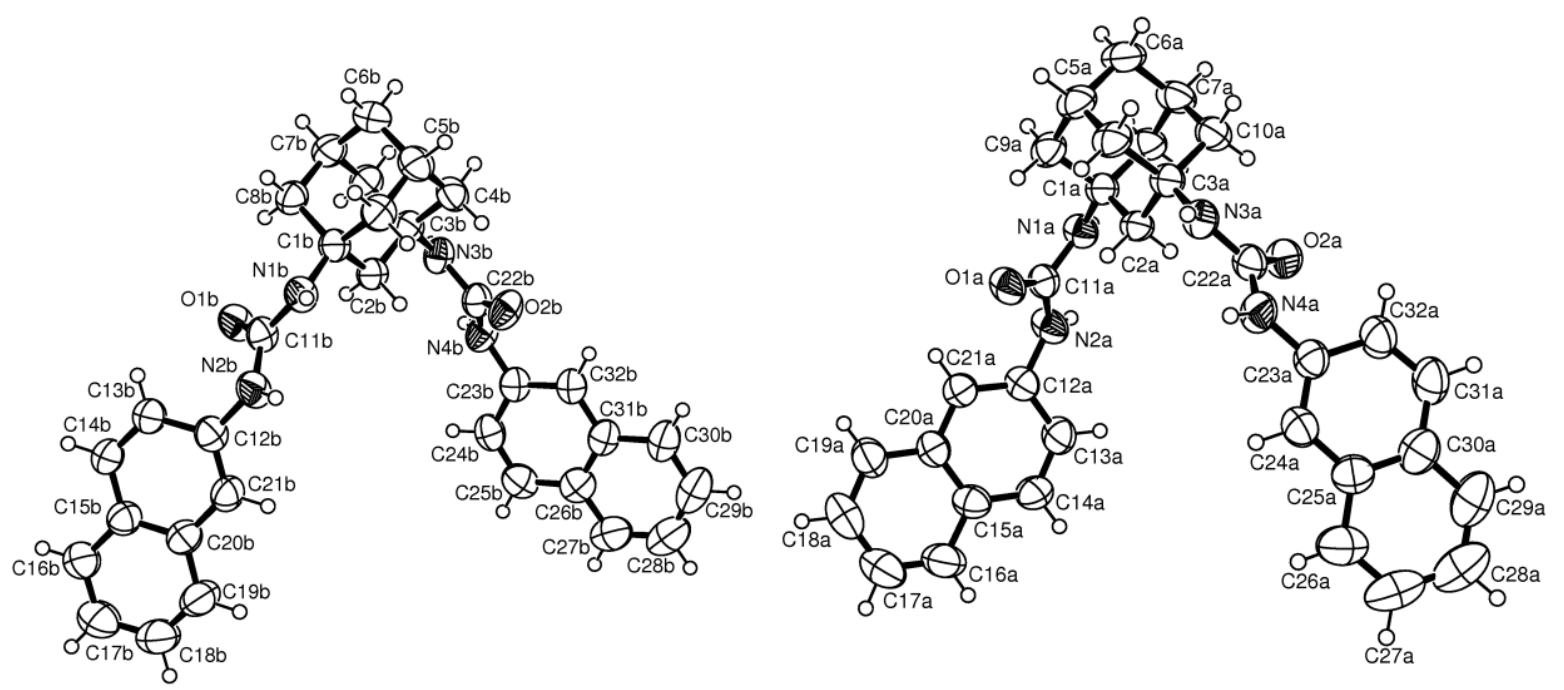

Fig. 4. Molecular structure of two symmetry-independent molecules of $\mathbf{1}$ that are related by a pseudo-inversion centre. Displacement ellipsoids are drawn at the probability level of $50 \%$ and hydrogen atoms have been depicted as spheres of arbitrary radii.

Binding of $\mathrm{H}_{2} \mathrm{PO}_{4}^{-}$with receptors 5 and 7 was also investigated by fluorescence spectrophotometry. Similar to the titrations with $\mathrm{F}^{-}$, addition of $\mathrm{Bu}_{4} \mathrm{NH}_{2} \mathrm{PO}_{4}$ to the $\mathrm{CH}_{3} \mathrm{CN}$ solution of 5 resulted in an increase of fluorescence, whereas $\mathrm{H}_{2} \mathrm{PO}_{4}{ }^{-}$quenched the fluorescence of 7. However, in the fluorescence spectra of 5 and 7 in the presence of $\mathrm{H}_{2} \mathrm{PO}_{4}^{-}$, no new bathochromic emission bands can be observed as in the titration of 7 with $\mathrm{F}^{-}$(Fig. 2 right). The finding is in accordance with the lower basicity of $\mathrm{H}_{2} \mathrm{PO}_{4}^{-}$than $\mathrm{F}^{-}$. Therefore, $\mathrm{H}_{2} \mathrm{PO}_{4}^{-}$cannot induce deprotonation of the urea $\mathrm{NH}$ in the $\mathrm{S}_{1}$ of 7 , whereas it probably takes place in the presence of very basic $\mathrm{F}^{-}$. The dependences of the fluorescence spectra on $\mathrm{H}_{2} \mathrm{PO}_{4}{ }^{-}$concentration were used to estimate the association constants of the complexes. The titration indicated that both receptors 5 and 7 form only 1:2 complexes with the association constants $\log \left(\beta_{12} / \mathrm{M}^{-2}\right)$ $8.50 \pm 0.01$ and $8.93 \pm 0.03$, respectively. The estimated association constants agree better with those measured by UV-vis spectroscopy than in the case of $\mathrm{F}^{-}$. The finding is logical since $\mathrm{H}_{2} \mathrm{PO}_{4}{ }^{-}$forms only complexes, whereas $\mathrm{F}^{-}$induces partial deprotonation in the excited state and the estimated equilibrium constants by fluorescence titration are cumulative composite constants (vide supra).

\subsection{Anion binding in the solid state}

The role of hydrogen bonding in assembling receptor-anion species in the solid state is visualized by crystal packing. X-ray structure analysis of the receptors and their anion complexes was performed. The analysis of the receptor molecules $\mathbf{1}$ and $\mathbf{2}$ is (see the 
Introduction section) focused on the topologies of hydrogen bonds to see the effect of adamantane moiety on the hydrogen bond network and to be correlated to their high selectivity for $\mathrm{H}_{2} \mathrm{PO}_{4}^{-}$. However, the difficulties in crystallization of receptor-anion complexes limited our analysis to successful cases with $\mathrm{H}_{2} \mathrm{PO}_{4}^{-}$and $\mathrm{OAc}^{-}$: $1 \cdot \mathrm{Bu}_{4} \mathrm{NH}_{2} \mathrm{PO}_{4}, \quad \mathbf{3} \cdot \mathrm{Bu}_{4} \mathrm{NH}_{2} \mathrm{PO}_{4}$, $\mathbf{5} \cdot \mathrm{Bu}_{4} \mathrm{NH}_{2} \mathrm{PO}_{4} \cdot 4 \mathrm{H}_{2} \mathrm{O}$, and $\mathbf{5} \cdot \mathrm{Bu}_{4} \mathrm{NOAc} \cdot 3 \mathrm{H}_{2} \mathrm{O}$ (see the Experimental section and Supporting info.). The hydrogen bonding is discussed in view of its role in formation of receptor-anion complexes.

The conformation of 1 is bent with an approximate $C_{2}$ symmetry (Fig. 4), while the unrestrained molecule 2 reveals an extended $C_{2}$-symmetric conformation (Supporting info. Fig. S110). The conformational differences explain dissimilarities in their crystal packing. Although donor and acceptor groups are the same in both compounds, hydrogen bonding patterns are different (Table 3). An asymmetric unit of receptor 1 comprises two molecules (Fig. 4) which are related by a pseudo-inversion centre located approximately at $0.25,0.50$, and 0.35 . Introduction of the bulky, conformationally rigid adamantyl group significantly influences molecular conformation which is of a tweezer-like shape, suitable for anion "fixation". The receptor molecule 1 forms two-dimensional hydrogen bonded layers parallel to (110) plane, described by graph-set notation $C_{1}^{1}(4) R_{2}^{1}(6) R_{2}^{2}(16) C_{2}^{2}(18) R_{6}^{6}(32)$ (Fig. 5) ${ }^{38}$ the separation of hydrophobic and hydrophilic regions is highly pronounced.

The receptor molecule 2 comprises a half of a molecule in the asymmetric unit (Supporting info. Fig. S111). The hydrogen bonding pattern of 2 is defined by chains with graph-set notation $C_{1}^{1}(4) R_{2}^{1}(6) R_{2}^{2}(16)$ (Supporting info. Fig. S111 and Table S1). ${ }^{38}$ Both structures, 1 and 2 exhibit $C_{1}^{1}(4)$ chains incorporating $R_{2}^{1}(6)$ and $R_{2}^{2}(16)$ rings. However, 1 reveals two additional motives including longer chains $C_{2}^{2}(18)$ and larger rings $R_{6}^{6}(32)$ than 2 . The receptor molecule 2 forms hydrogen bonds with two neighbours, while 1 bonds with three neighbours. The tweezer-like shape of $\mathbf{1}$ imposed by the bulky and rigid adamantane moiety with three hydrogen bonds is better suited to bind anions. The receptor molecule $\mathbf{2}$ is linear and suited to form hydrogen bonding in one direction, only. Crystal structure of a bisurea receptor similar to $\mathbf{2}$ has recently been reported by Steed and co-workers. ${ }^{39}$ 


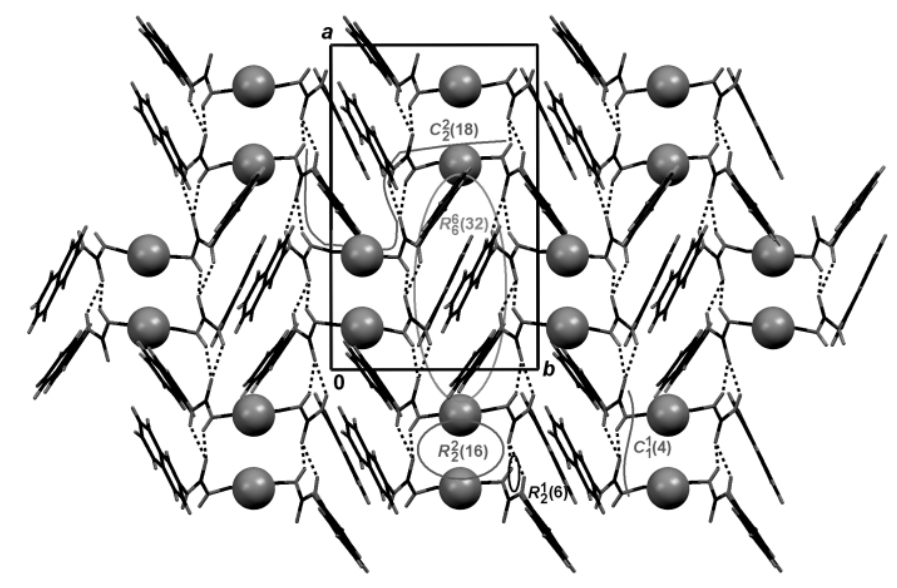

Fig. 5. Two-dimensional hydrogen bonding pattern in 1: the layers are parallel to the plane (110) and topology is $C_{1}^{1}(4) R_{2}^{1}(6) R_{2}^{2}(16) C_{2}^{2}(18) R_{6}^{6}(32) .{ }^{38}$ Adamantyl groups are shown as gray spheres of arbitrary radii and $\mathrm{C}-\mathrm{H} \cdots \mathrm{O}$ hydrogen bonds have been omitted for clarity. Hydrogen bonded chains are separated by hydrophobic columns.

$\mathrm{H}_{2} \mathrm{PO}_{4}^{-}$is prone to self-assembling via hydrogen bonds using both its donor and acceptor functionalities. A search of Cambridge Crystallographic Structure Database (v5.33, the release $2012)^{40}$ revealed a total of 421 crystal structures with dihydrogenphosphate anion; 319 (75\%) of them are self-assembled anions via hydrogen bonding. The two most populated motifs are: $R_{2}^{2}(8)$ rings (found in 172 structures, i.e. in $54 \%$ examples) and a single $\mathrm{P}-\mathrm{H}-\mathrm{O} \cdots \mathrm{O}=\mathrm{P}$ bond, usually forming $D_{1}^{1}(2)$ and $C_{1}^{1}(4)$ motifs (found in 118 structures, i.e. in $37 \%$ examples) (Scheme 1). More complicated motifs with larger rings are rare. However, many motifs of different topologies are formed by $R_{2}^{2}(8), D_{1}^{1}(4)$ and $C_{1}^{1}(4)$ combinations as illustrated by here observed topologies.<smiles>O=P1(O)O[C@H]2OP(=O)(O)O[C@H](O1)O2</smiles>

$R_{2}^{2}(8)$<smiles></smiles>

Scheme 1. 
Complexes of $\mathbf{1} \cdot \mathrm{Bu}_{4} \mathrm{NH}_{2} \mathrm{PO}_{4}$ and $\mathbf{3} \cdot \mathrm{Bu}_{4} \mathrm{NH}_{2} \mathrm{PO}_{4}$ were crystallized with $1: 1$ stoichiometry. Their unit cells are large, and asymmetric units contain 2 and 4 complex units, respectively. In their crystal structures there are discrete hydrogen bonded tetramers: $\left(\mathbf{1} \cdot \mathrm{Bu}_{4} \mathrm{NH}_{2} \mathrm{PO}_{4}\right)_{4}$ and $\left(3 \cdot \mathrm{Bu}_{4} \mathrm{NH}_{2} \mathrm{PO}_{4}\right)_{4}$ (Fig. 6, and Supporting info. Fig. S114), and in both structures $3 \mathrm{D}$ packing is achieved through dispersion interactions, only. A poor quality of these crystals might be due to weak interactions among tetramers. The cores consisting of four anions connected through $\mathrm{H}$-bonds are encapsulated by receptor molecules $\mathbf{1}$ and $\mathbf{3}$, forming complexes with the stoichiometry $\left(1 \cdot \mathrm{Bu}_{4} \mathrm{NH}_{2} \mathrm{PO}_{4}\right)_{4}$ and $\left(3 \cdot \mathrm{Bu}_{4} \mathrm{NH}_{2} \mathrm{PO}_{4}\right)_{4}$, respectively (Fig. 7, Table 3$)$. In both complexes, there are extensive hydrogen bonds involving anion $\cdots$ anion using their donor and acceptor functionalities $(\mathrm{O}-\mathrm{H} \cdots \mathrm{O})$, whereas the urea $\mathrm{NH}$ groups of the receptors are proton donors in receptor $\cdots$ anion $(\mathrm{N}-\mathrm{H} \cdots \mathrm{O})$ hydrogen bonds. In $\mathrm{H}_{2} \mathrm{PO}_{4}^{-}$, the negative charge of the deprotonated oxygen atom is delocalized onto the $\mathrm{P}=\mathrm{O}$ group also. These hydrogen boned cores are shielded by hydrophobic naphthyl and adamantyl groups (Fig. 8). However, the orientations of the naphthyl groups of the receptor $\mathbf{1}$ in the complex $\mathbf{1} \cdot \mathrm{Bu}_{4} \mathrm{NH}_{2} \mathrm{PO}_{4}$ are not in favour of $\pi$ interactions whereas in the receptor 3 of the complex $3 \cdot \mathrm{Bu}_{4} \mathrm{NH}_{2} \mathrm{PO}_{4}$ these interactions are observed (Supporting info. Table S2). Hydrogen bonded tetrahedral assemblies of $\mathrm{H}_{2} \mathrm{PO}_{4}^{-}$ anions similar to ours have been reported. ${ }^{41}$
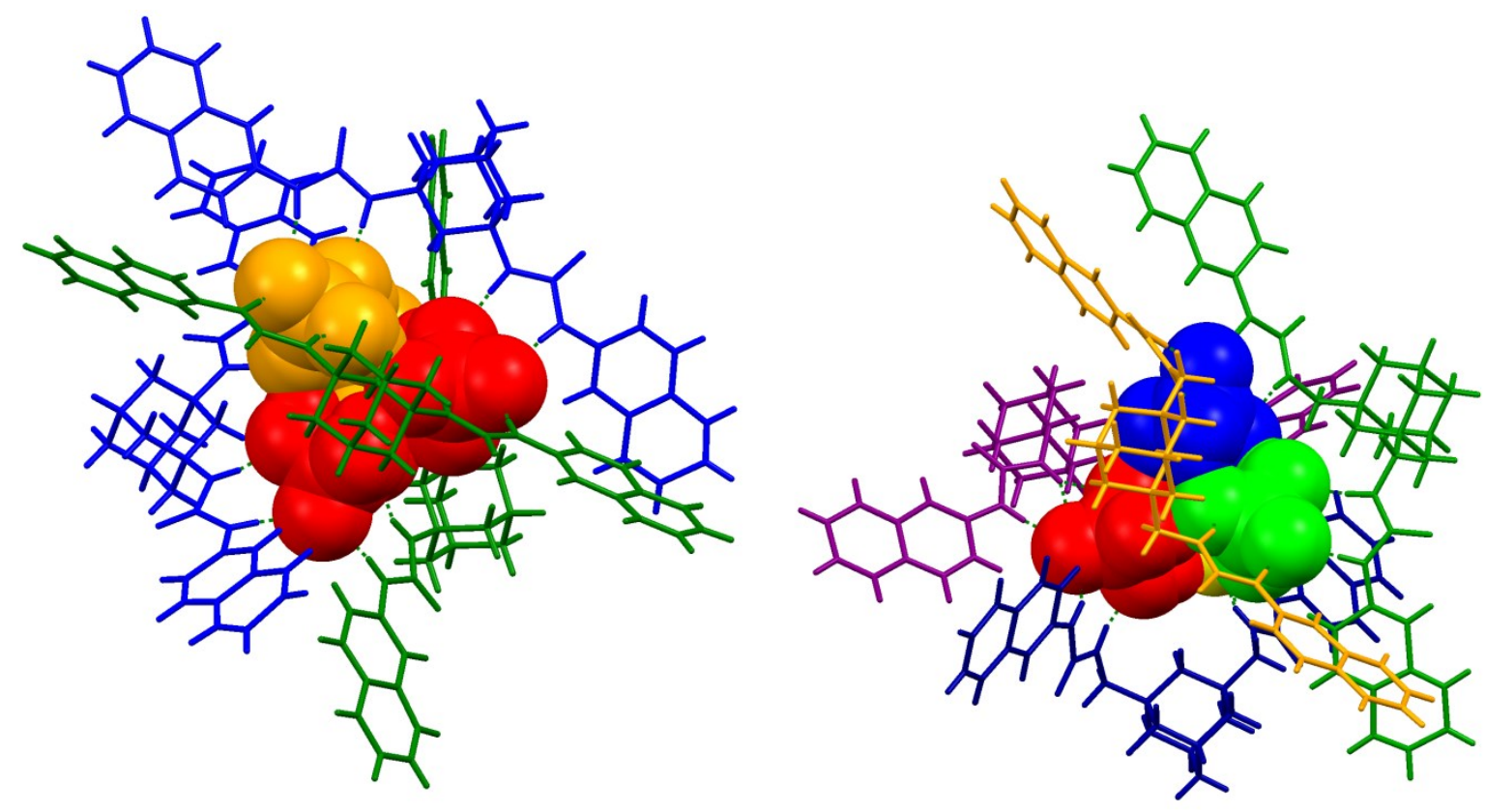

Fig. 6. Tetrahedral assemblies of $\left(\mathbf{1} \cdot \mathrm{H}_{2} \mathrm{PO}_{4}\right)_{4}$ (left) and $\left(\mathbf{3} \cdot \mathrm{H}_{2} \mathrm{PO}_{4}\right)_{4}$ units (right). The receptors $\mathbf{1}$ and $\mathbf{3}$ (wire models) are hydrogen bonded to $\mathrm{H}_{2} \mathrm{PO}_{4}$ anions, shown as van der Waals spheres. Symmetry (in)equivalence is colour-coded. 

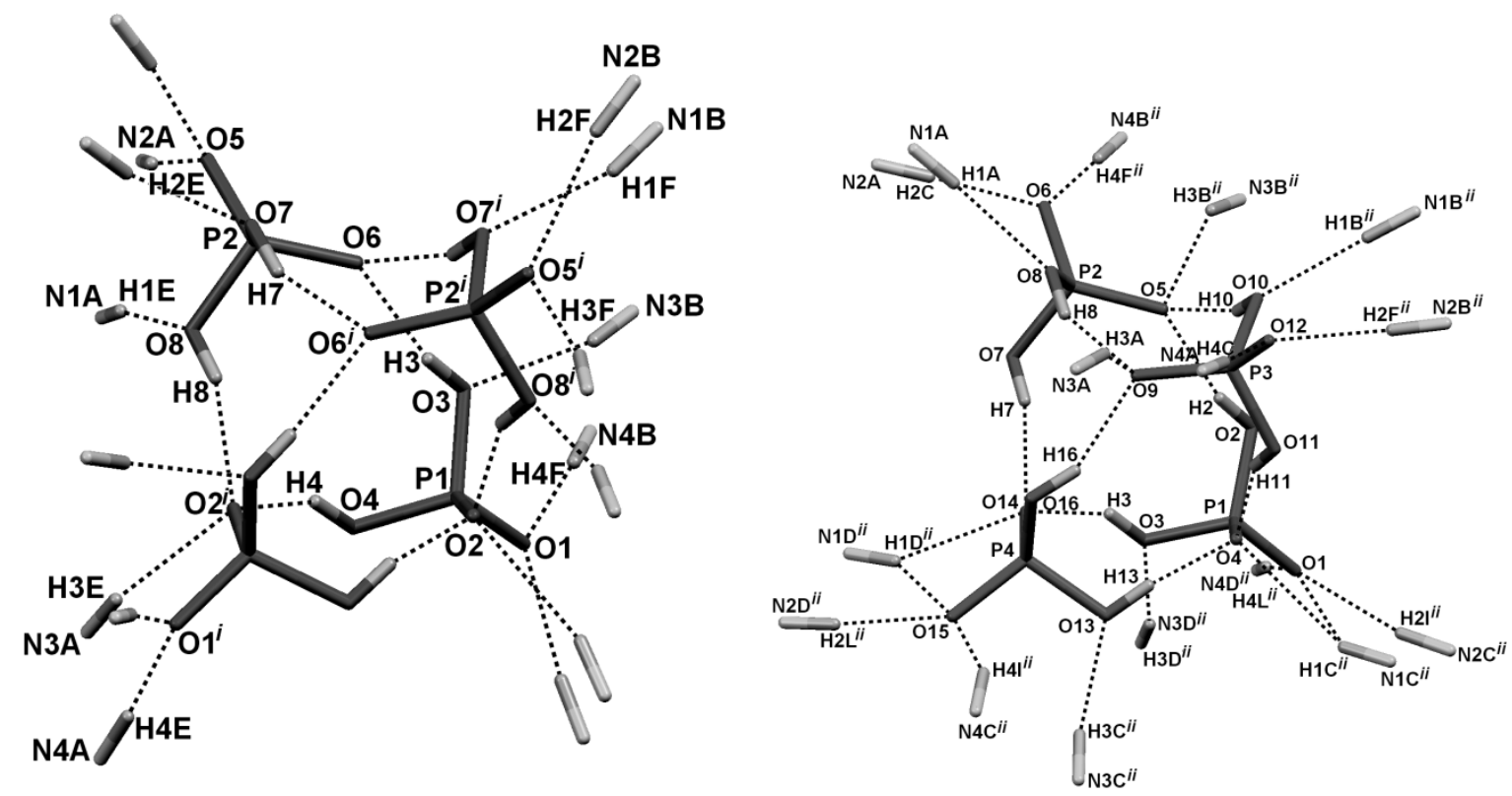

Fig. 7. Hydrogen bonds involving the dihydrogenphosphate tetrahedra in $\left(\mathbf{1} \cdot \mathrm{H}_{2} \mathrm{PO}_{4}\right)_{4}(\mathrm{left})$ and $\left(\mathbf{3} \cdot \mathrm{H}_{2} \mathrm{PO}_{4}\right)_{4}$ units (right). Only symmetry-independent hydrogen bonds are labeled in a). Symmetry operators: $i) x, 1-y,-z ; i i)-1+x, y, z$.

In the structure of $\mathbf{5} \cdot \mathrm{Bu}_{4} \mathrm{NH}_{2} \mathrm{PO}_{4} \cdot 4 \mathrm{H}_{2} \mathrm{O}$, system of hydrogen bonds is even more complex due to four crystal water molecules. In addition to hydrogen bonds involving receptor $\cdots$ anion $(\mathrm{N}-\mathrm{H} \cdots \mathrm{O})$ and anion $\cdots$ anion $(\mathrm{O}-\mathrm{H} \cdots \mathrm{O})$ there are interactions between the anion and water molecules $(\mathrm{O}-\mathrm{H} \cdots \mathrm{O})$ where both species exchange donor and acceptor functions, water $\cdots$ water molecules $(\mathrm{O}-\mathrm{H} \cdots \mathrm{O})$, and water $\cdots$ receptor $(\mathrm{O}-\mathrm{H} \cdots \mathrm{O}=\mathrm{C})$ (Supporting info. Fig. S112).

To compare hydrogen bonds in the receptor-anion complexes of dihydrogenphosphate with the receptors $\mathbf{1}, \mathbf{3}$, and $\mathbf{5}$ one can summarize: a) all three complexes exhibit receptor $\cdots$ anion hydrogen bonds essential for anion recognition, b) dihydrogenphosphate anion comprises donor and acceptor functionalities and anion $\cdots$ anion hydrogen bonds are inavoidable, and c) complex $5 \cdot \mathrm{Bu}_{4} \mathrm{NH}_{2} \mathrm{PO}_{4} \cdot 4 \mathrm{H}_{2} \mathrm{O}$ crystallizes as tetrahydrate where water molecules increase significantly hydrogen bonding interactions. Generally, similar hydrogen bonding patterns may also be present in the complexes in the solution. However, formation of large aggregates that can be represented as $\left(\mathbf{1} \cdot \mathrm{H}_{2} \mathrm{PO}_{4}\right)_{4}$ and $\left(\mathbf{3} \cdot \mathrm{H}_{2} \mathrm{PO}_{4}\right)_{4}$ probably does not take place due to unfavorable entropy.

Receptor 5 (Fig. 8), like 1, lacks the methylene spacers on adamantyl cage. Its overall molecular conformation is adjusted to expose $\mathrm{NH}$ groups for hydrogen bonding with $\mathrm{Y}$-shaped $\mathrm{OAc}^{-}$in $\mathbf{5} \cdot \mathrm{Bu}_{4} \mathrm{NOAc} \cdot 3 \mathrm{H}_{2} \mathrm{O}$ (Table 3) and tetrahedral $\mathrm{H}_{2} \mathrm{PO}_{4}^{-}$in $\mathbf{5} \cdot \mathrm{Bu}_{4} \mathrm{NH}_{2} \mathrm{PO}_{4} \cdot 4 \mathrm{H}_{2} \mathrm{O}$ 
(Supporting info. Table S1). In the crystal of $5 \cdot \mathrm{Bu}_{4} \mathrm{NOAc}_{3} \cdot 3 \mathrm{H}_{2} \mathrm{O}$ a hydrogen bonded chain in the direction [100] includes receptor ${ }^{\cdots} \mathrm{OAc}^{-}(\mathrm{N}-\mathrm{H} \cdots \mathrm{O})$, crystal water $\cdots \mathrm{OAc}^{-}(\mathrm{O}-\mathrm{H} \cdots \mathrm{O})$, and water $\cdots$ receptor $(\mathrm{O}-\mathrm{H} \cdots \mathrm{O}=\mathrm{C})$ interactions (Table 3, Fig. 9, and Supporting info Fig. S113).

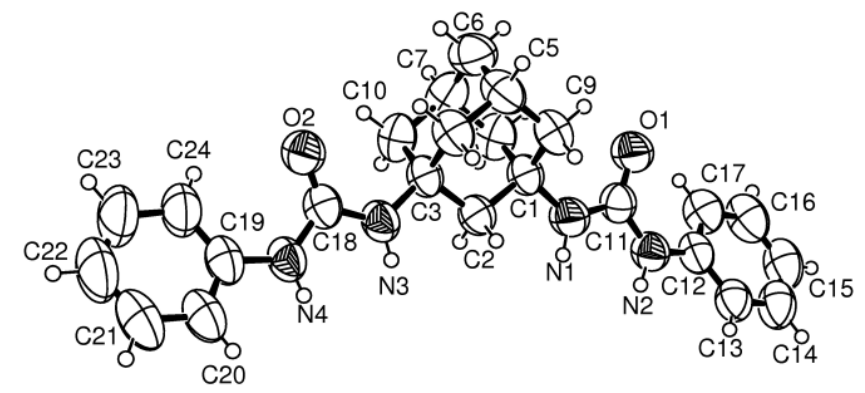

Fig. 8. Molecular structure of receptor moiety 5 in its complex $5 \cdot \mathrm{Bu}_{4} \mathrm{NOAc} \cdot 3 \mathrm{H}_{2} \mathrm{O}$. The same atom numbering scheme is applied to the phosphate complex. Displacement ellipsoids are drawn at the probability level of $50 \%$ and hydrogen atoms have been depicted as spheres of arbitrary radii.

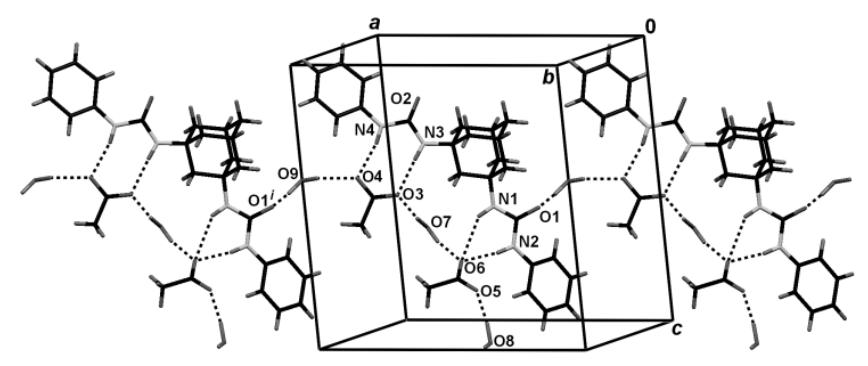

Fig. 9. Crystal packing of $5 \cdot \mathrm{Bu}_{4} \mathrm{NOAc} \cdot 3 \mathrm{H}_{2} \mathrm{O}$ : a) a chain consisting of hydrogen bonded units extending in the direction [100] with graph-set $D_{1}^{1}(2) D_{1}^{1}(2) D_{1}^{1}(2) D_{1}^{1}(2) D_{1}^{1}(2) D_{1}^{1}(2) D_{1}^{1}(2) D_{1}^{1}(2)$. Symmetry operator: $i$ ) $1+x, y, z$;

\section{Conclusion}

Adamantanebisurea receptors 5-9 were synthesized and their complexation with $\mathrm{F}^{-}, \mathrm{Cl}^{-}$ , $\mathrm{Br}^{-}, \mathrm{OAc}^{-}, \mathrm{NO}_{3}^{-} \mathrm{HSO}_{4}^{-}$, and $\mathrm{H}_{2} \mathrm{PO}_{4}^{-}$in the solution investigated. The receptors form stable complexes with all anions except with $\mathrm{NO}_{3}^{-}$. The complexation ability in the $\mathrm{CH}_{3} \mathrm{CN}$ solution can be correlated with the basicity of anion, as well as with the acidity of the urea N-H. However, these differences become less pronounced in the more competitive solvent, DMSO. Moreover, molecular structure of the receptors plays an important role in the anion complexation. The analysis of the receptor molecules $\mathbf{1}$ and $\mathbf{2}$ by X-ray crystallography highlights the importance of the adamantane unit for the preorganization of the receptor in the 
tweezer-like conformation for the optimal formation of hydrogen bonding network and high selectivity for $\mathrm{H}_{2} \mathrm{PO}_{4}{ }^{-}$. Furthermore, incorporation of the methylene spacers between the adamantane and the urea significantly increases stability of the complexes with anions. The most stable complexes were formed with $\mathrm{F}^{-}$and $\mathrm{H}_{2} \mathrm{PO}_{4}^{-}$. In addition, receptors 7-9 in the presence of basic $\mathrm{F}^{-}$probably undergo deprotonation in the excited state resulting in different values of the estimated association constants by UV-vis and fluorescence titrations. Since UVvis and fluorescence response of $\mathbf{7}$ and $\mathbf{8}$ exhibits significant spectral shifts on addition of anions, these derivatives may find applications as ratiometric UV-vis and fluorescence indicators. Complexation with $\mathrm{H}_{2} \mathrm{PO}_{4}^{-}$in the solid state was achieved in three examples: $\mathbf{1} \cdot \mathrm{Bu}_{4} \mathrm{NH}_{2} \mathrm{PO}_{4}, \mathbf{3} \cdot \mathrm{Bu}_{4} \mathrm{NH}_{2} \mathrm{PO}_{4}, \mathbf{5} \cdot \mathrm{Bu}_{4} \mathrm{NH}_{2} \mathrm{PO}_{4} \cdot 4 \mathrm{H}_{2} \mathrm{O}$. All $\mathrm{H}_{2} \mathrm{PO}_{4}{ }^{-}$complexes are characterized by receptor ${ }^{\cdots} \mathrm{H}_{2} \mathrm{PO}_{4}^{-}$hydrogen bonds, essential for the anion recognition. In addition, $\mathrm{H}_{2} \mathrm{PO}_{4}^{-}$ comprises donor and acceptor functionalities, and therefore $\mathrm{H}_{2} \mathrm{PO}_{4}{ }^{-}{ }^{-} \mathrm{H}_{2} \mathrm{PO}_{4}{ }^{-}$hydrogen bonds are also formed, additionally stabilizing the structures. The information of the anion coordination presented in this study is of significant value in the design of new receptors that will be screened in the de novo approach, and eventual preparation of new sensor molecules characterized by better selectivity.

\section{Experimental section}

General. Compounds 5-9 were prepared according to a modification of the published procedure. ${ }^{17}$ Adamantane diacids were prepared in the laboratory according to known procedure. ${ }^{42} \beta$-Naphthyl amine and naphthalene-2-carboxylic acid were obtained from the usual commercial sources. ${ }^{1} \mathrm{H}$ and ${ }^{13} \mathrm{C}$ NMR spectra were recorded on a Bruker Spectrometer at 300 or $600 \mathrm{MHz}$. All NMR spectra were measured in $\mathrm{CD}_{3} \mathrm{CN}$ or $d_{6}$-DMSO using tetramethylsilane as a reference. The UV-vis measurements were performed on a Varain Carry 100 spectrometer, and fluorescence on a Cary Eclipse Varian spectrometer. The compounds were dissolved in $\mathrm{CH}_{3} \mathrm{CN}$ (J. T. Baker, HPLC grade) or DMSO (Sigma-Aldrich or Fluka, UV-spectroscopy grade).

\subsection{UV-vis titrations}

The anion receptor was dissolved in $\mathrm{CH}_{3} \mathrm{CN}$ or DMSO in the concentration range $\approx 10^{-}$ ${ }^{5} \mathrm{M}$, corresponding to the maximum of absorbance in the range $0.5-1.0$. The solution of the receptor was placed in a quartz cuvette $(1,3$ or $30 \mathrm{~mL})$ and small volumes $(5-500 \mu \mathrm{L})$ of the following solutions of anion were added: $\mathrm{Bu}_{4} \mathrm{NF}\left(1 \mathrm{M}\right.$ in THF, containing <wt $5 \% \mathrm{H}_{2} \mathrm{O}$, diluted 
with $\mathrm{CH}_{3} \mathrm{CN}$ or DMSO to $\left.1 \times 10^{-3} \mathrm{M}\right), \mathrm{Bu}_{4} \mathrm{NCl}, \mathrm{Bu}_{4} \mathrm{NBr}, \mathrm{Bu}_{4} \mathrm{NOAc}_{2} \mathrm{Bu}_{4} \mathrm{NHSO}_{4}, \mathrm{Bu}_{4} \mathrm{NNO}_{3}$ or $\mathrm{Bu}_{4} \mathrm{NH}_{2} \mathrm{PO}_{4}$ (from $1 \times 10^{-2}$ to $1 \times 10^{-5} \mathrm{M}$ in $\mathrm{CH}_{3} \mathrm{CN}$ or DMSO). After each addition, UV-vis spectra were recorded. The titrations were performed at $\mathrm{rt}\left(20^{\circ} \mathrm{C}\right)$. The data was analyzed by SPECFIT program to reveal the stability constants of the complexes.

\subsection{Fluorescence titrations}

The anion receptor was dissolved in $\mathrm{CH}_{3} \mathrm{CN}$ or DMSO in the concentration range $\approx 10^{-}$ ${ }^{6} \mathrm{M}$, corresponding to the maximum of absorbance in the range 0.07-0.1. The solution of the receptor was placed in a quarz cuvette $(2 \mathrm{~mL})$ and small volumes $(5-100 \mu \mathrm{L})$ of the solutions of anion are added: $\mathrm{Bu}_{4} \mathrm{NF}\left(1 \mathrm{M}\right.$ in THF, containing $<$ wt $5 \% \mathrm{H}_{2} \mathrm{O}$, diluted with DMSO to $1 \times 10^{-}$ ${ }^{3} \mathrm{M}$ ), or $\mathrm{Bu}_{4} \mathrm{NH}_{2} \mathrm{PO}_{4}$ (from $1 \times 10^{-2}$ to $1 \times 10^{-5} \mathrm{M}$ in DMSO). After each addition, fluorescence spectra were recorded, using the excitation wavelength at $295 \mathrm{~nm}$, or emission at $370 \mathrm{~nm}$. The titrations were performed at $\mathrm{rt}\left(20^{\circ} \mathrm{C}\right)$.

\subsection{NMR titrations}

In a NMR tube was placed $1 \mathrm{~mL}$ of the DMSO- $d_{6}$ solution of receptor 5 or 7 . The concentration of the receptor in the NMR experiment was typically $0.05 \mathrm{M}$. To the solution in the tube was added a solution of $\mathrm{Bu}_{4} \mathrm{NF}\left(1 \mathrm{M}\right.$ in THF, containing $<$ wt $\left.5 \% \mathrm{H}_{2} \mathrm{O}\right)$ or $(\sim 0.5 \mathrm{M}$ in DMSO- $d_{6}$ ). The concentrations of the salt ranged from $0.01-0.1 \mathrm{M}$, reaching the maximal ratio of anion:receptor $=30: 1$. After each addition, NMR spectra were recorded. The association constants were determined by fitting the dependence of the chemical shift of the NH signal $(\Delta \delta)$ to the anion concentration, using EQNMR program. ${ }^{43}$

Table 3. Geometric parameters of hydrogen bonds.

\begin{tabular}{|c|c|c|c|c|c|}
\hline & $D-\mathrm{H} / \AA$ & $\mathrm{H} \cdots A / \AA$ & $D \cdots A / \AA$ & $D-\mathrm{H}^{\prime} \cdots A /^{\circ}$ & Symm. op. on $A$ \\
\hline $\begin{array}{c}\mathbf{1} \\
\mathrm{N} 1 \mathrm{~A}-\mathrm{H} 1 \mathrm{E} \cdots \mathrm{O} 2 \mathrm{~A}\end{array}$ & 0.86 & 2.31 & $2.906(4)$ & 127 & $-x, 1 / 2+y, z$ \\
\hline N1B-H1F ‥O1A & 0.86 & 2.42 & $2.931(4)$ & 119 & $x,-1+y, z$ \\
\hline $\mathrm{N} 2 \mathrm{~A}-\mathrm{H} 2 \mathrm{E} \cdots \mathrm{O} 2 \mathrm{~A}$ & 0.86 & 2.18 & $2.913(4)$ & 143 & $-x, 1 / 2+y, z$ \\
\hline $\mathrm{N} 2 \mathrm{~B}-\mathrm{H} 2 \mathrm{~F} \cdots \mathrm{O} 1 \mathrm{~A}$ & 0.86 & 2.12 & $2.876(4)$ & 146 & $x,-1+y, z$ \\
\hline $\mathrm{N} 3 \mathrm{~A}-\mathrm{H} 3 \mathrm{E} \cdots \mathrm{O} 2 \mathrm{~B}$ & 0.86 & 2.49 & $2.973(4)$ & 116 & $x, 1+y, z$ \\
\hline N3B-H3F ‥ O1B & 0.86 & 2.35 & $2.959(4)$ & 128 & $1-x,-1 / 2+y, z$ \\
\hline
\end{tabular}


Blažek, V.; Molčanov, K.; Mlinarić-Majerski, K.; Kojić-Prodić, B.; Basarić, N. Adamantane bisurea derivatives: anion binding in the solution and in the solid state. Tetrahedron. 2013, 69, 517-526. DOI: 10.1016/j.tet.2012.11.030 - Accepted Version

\begin{tabular}{|c|c|c|c|c|c|}
\hline $\mathrm{N} 4 \mathrm{~A}-\mathrm{H} 4 \mathrm{E} \cdots \mathrm{O} 2 \mathrm{~B}$ & 0.86 & 2.09 & $2.841(4)$ & 145 & $x, 1+y, z$ \\
\hline N4B-H4F $\cdots$ O1B & 0.86 & 2.19 & $2.942(4)$ & 146 & $1-x,-1 / 2+y, z$ \\
\hline $\mathrm{C} 4 \mathrm{~B}-\mathrm{H} 4 \mathrm{C} \cdots \mathrm{O} 2 \mathrm{~B}$ & 0.97 & 2.39 & $2.995(5)$ & 120 & $x, y, z$ \\
\hline $\mathrm{C} 8 \mathrm{~B}-\mathrm{H} 8 \mathrm{C} \cdots \mathrm{O} 1 \mathrm{~B}$ & 0.97 & 2.43 & $3.036(5)$ & 120 & $x, y, z$ \\
\hline C9A-H9A $\cdots$ O1A & 0.97 & 2.47 & $3.052(5)$ & 118 & $x, y, z$ \\
\hline C10A- & 0.97 & 2.40 & $3.001(5)$ & 120 & $x, y, z$ \\
\hline \multicolumn{6}{|l|}{$\mathrm{H} 10 \mathrm{~A} \cdots \mathrm{O} 2 \mathrm{~A}$} \\
\hline $\mathrm{C} 32 \mathrm{~B}-\mathrm{H} 32 \mathrm{~B} \cdots \mathrm{O} 2 \mathrm{~B}$ & 0.93 & 2.58 & $2.930(5)$ & 103 & $x, y, z$ \\
\hline \multicolumn{6}{|l|}{$\mathbf{1} \cdot \mathrm{Bu}_{4} \mathrm{NH}_{2} \mathrm{PO}_{4}$} \\
\hline N1A-H1E $\cdots$ O8 & 0.86 & 2.24 & $3.08(4)$ & 165 & $x, y, z$ \\
\hline 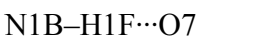 & 0.86 & 2.07 & $2.90(4)$ & 161 & $x, 1-y,-z$ \\
\hline N2A-H2E $\cdots \mathrm{O} 5$ & 0.86 & 2.00 & $2.84(5)$ & 164 & $x, y, z$ \\
\hline $\mathrm{N} 2 \mathrm{~B}-\mathrm{H} 2 \mathrm{~F} \cdots \mathrm{O} 5$ & 0.86 & 2.33 & $3.15(4)$ & 160 & $x, 1-y,-z$ \\
\hline $\mathrm{O} 3-\mathrm{H} 3 \cdots \mathrm{O} 6$ & 0.82 & 1.84 & $2.63(3)$ & 162 & $x, y, z$ \\
\hline $\mathrm{N} 3 \mathrm{~A}-\mathrm{H} 3 \mathrm{E} \cdots \mathrm{O} 2$ & 0.86 & 2.32 & $3.13(4)$ & 158 & $x, 1-y,-z$ \\
\hline $\mathrm{N} 3 \mathrm{~B}-\mathrm{H} 3 \mathrm{~F} \cdots \mathrm{O} 3$ & 0.86 & 2.14 & $2.97(4)$ & 160 & $x, y, z$ \\
\hline $\mathrm{O} 4-\mathrm{H} 4 \cdots \mathrm{O} 2$ & 0.82 & 1.91 & $2.65(3)$ & 150 & $x, 1-y,-z$ \\
\hline $\mathrm{N} 4 \mathrm{~A}-\mathrm{H} 4 \mathrm{E} \cdots \mathrm{O} 1$ & 0.86 & 2.04 & $2.89(4)$ & 172 & $x, 1-y,-z$ \\
\hline $\mathrm{N} 4 \mathrm{~B}-\mathrm{H} 4 \mathrm{~F} \cdots \mathrm{O} 1$ & 0.86 & 2.05 & $2.92(3)$ & 172 & $x, y, z$ \\
\hline $\mathrm{O} 7-\mathrm{H} 7 \cdots \mathrm{O} 6$ & 0.82 & 1.72 & $2.56(3)$ & 156 & $x, 1-y,-z$ \\
\hline $\mathrm{O} 8-\mathrm{H} 8 \cdots \mathrm{O} 2$ & 0.82 & 1.89 & $2.66(3)$ & 157 & $x, 1-y,-z$ \\
\hline \multicolumn{6}{|l|}{ 3 $\cdot \mathrm{Bu}_{4} \mathrm{NH}_{2} \mathrm{PO}_{4}$} \\
\hline N1A-H1A $\cdots$ O 8 & 0.86 & 2.14 & 2.998 & 176 & $x, y, z$ \\
\hline N1B-H1B $\cdots \mathrm{O} 10$ & 0.86 & 2.15 & 2.994 & 167 & $1+x, y, z$ \\
\hline $\mathrm{N} 1 \mathrm{C}-\mathrm{H} 1 \mathrm{C} \cdots \mathrm{O} 4$ & 0.86 & 2.44 & 3.152 & 141 & $1+x, y, z$ \\
\hline N1D-H1D O14 & 0.86 & 2.34 & 3.100 & 149 & $1+x, y, z$ \\
\hline 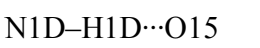 & 0.86 & 2.55 & 3.276 & 143 & $1+x, y, z$ \\
\hline
\end{tabular}


Blažek, V.; Molčanov, K.; Mlinarić-Majerski, K.; Kojić-Prodić, B.; Basarić, N. Adamantane bisurea derivatives: anion binding in the solution and in the solid state. Tetrahedron. 2013, 69, 517-526. DOI: 10.1016/j.tet.2012.11.030 - Accepted Version

\begin{tabular}{|c|c|c|c|c|c|}
\hline $\mathrm{O} 2-\mathrm{H} 2 \cdots \mathrm{O} 5$ & 0.82 & 1.80 & $2.594(8)$ & 161 & $x, y, z$ \\
\hline $\mathrm{N} 2 \mathrm{~A}-\mathrm{H} 2 \mathrm{C} \cdots \mathrm{O} 6$ & 0.86 & 1.98 & 2.836 & 172 & $x, y, z$ \\
\hline $\mathrm{N} 2 \mathrm{~B}-\mathrm{H} 2 \mathrm{~F} \cdots \mathrm{O} 12$ & 0.86 & 1.99 & 2.845 & 178 & $1+x, y, z$ \\
\hline $\mathrm{N} 2 \mathrm{C}-\mathrm{H} 2 \mathrm{I} \cdots \mathrm{O} 1$ & 0.86 & 1.99 & 2.830 & 166 & $1+x, y, z$ \\
\hline $\mathrm{N} 2 \mathrm{D}-\mathrm{H} 2 \mathrm{~L} \cdots \mathrm{O} 15$ & 0.86 & 1.99 & 2.840 & 173 & $1+x, y, z$ \\
\hline $\mathrm{O} 3-\mathrm{H} 3 \cdots \mathrm{O} 14$ & 0.82 & 1.85 & $2.592(7)$ & 150 & $x, y, z$ \\
\hline $\mathrm{N} 3 \mathrm{~A}-\mathrm{H} 3 \mathrm{~A} \cdots \mathrm{O} 9$ & 0.86 & 2.30 & 3.068 & 148 & $x, y, z$ \\
\hline N3B-H3B $\cdots \mathrm{O} 5$ & 0.86 & 2.25 & 3.003 & 147 & $1+x, y, z$ \\
\hline $\mathrm{N} 3 \mathrm{C}-\mathrm{H} 3 \mathrm{C} \cdots \mathrm{O} 13$ & 0.86 & 2.16 & 2.999 & 167 & $1+x, y, z$ \\
\hline N3D-H3D $\cdots \mathrm{O} 3$ & 0.86 & 2.13 & 2.947 & 158 & $1+x, y, z$ \\
\hline $\mathrm{N} 4 \mathrm{~A}-\mathrm{H} 4 \mathrm{C} \cdots \mathrm{O} 12$ & 0.86 & 2.03 & 2.892 & 178 & $x, y, z$ \\
\hline N4B-H4F $\cdots$ O6 & 0.86 & 2.05 & 2.913 & 180 & $1+x, y, z$ \\
\hline N4C-H4I $\cdots \mathrm{O} 15$ & 0.86 & 2.03 & 2.811 & 151 & $1+x, y, z$ \\
\hline N4D-H4L $\cdots \mathrm{O} 1$ & 0.86 & 1.97 & 2.827 & 174 & $1+x, y, z$ \\
\hline $\mathrm{O} 7-\mathrm{H} 7 \cdots \mathrm{O} 14$ & 0.82 & 1.81 & $2.596(7)$ & 159 & $x, y, z$ \\
\hline 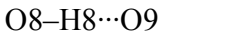 & 0.82 & 1.86 & $2.615(8)$ & 153 & $x, y, z$ \\
\hline $\mathrm{O} 10-\mathrm{H} 10 \cdots \mathrm{O} 5$ & 0.82 & 1.84 & $2.613(8)$ & 157 & $x, y, z$ \\
\hline \multicolumn{6}{|l|}{$\mathbf{5} \cdot \mathrm{Bu}_{4} \mathrm{NOAc} \cdot 3 \mathrm{H}_{2} \mathrm{O}$} \\
\hline 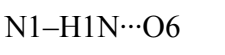 & 0.86 & 2.44 & $3.184(4)$ & 146 & $x, y, z$ \\
\hline $\mathrm{N} 2-\mathrm{H} 2 \mathrm{~N} \cdots \mathrm{O} 6$ & 0.86 & 1.92 & $2.776(4)$ & 171 & $x, y, z$ \\
\hline 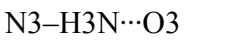 & 0.86 & 2.01 & $2.868(3)$ & 172 & $x, y, z$ \\
\hline 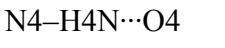 & 0.86 & 2.01 & $2.849(4)$ & 166 & $x, y, z$ \\
\hline O7-H7A $\cdots$ O6 & $0.97(3)$ & $1.72(4)$ & $2.678(5)$ & $168(4)$ & $x, y, z$ \\
\hline O7-H7B $\cdots \mathrm{O} 3$ & $0.95(4)$ & $1.93(4)$ & $2.867(6)$ & $169(4)$ & $x, y, z$ \\
\hline $\mathrm{O} 8-\mathrm{H} 8 \mathrm{C} \cdots \mathrm{O} 5$ & $0.97(2)$ & $1.76(3)$ & $2.721(5)$ & $171(5)$ & $x, y, z$ \\
\hline O9-H9C $\cdots \mathrm{O} 1$ & $0.96(5)$ & $2.08(6)$ & $2.926(4)$ & $147(6)$ & $1+x, y, z$ \\
\hline O9-H9D $\cdots \mathrm{O} 4$ & $0.95(3)$ & $2.01(3)$ & $2.811(5)$ & $140(3)$ & $x, y, z$ \\
\hline
\end{tabular}




\subsection{Crystallography}

Single-crystals for X-ray measurements were obtained by slow crystallization from toluene (receptor 1) methanol (receptor 2) or acetone $\left(5 \cdot \mathrm{Bu}_{4} \mathrm{NH}_{2} \mathrm{PO}_{4} \cdot 4 \mathrm{H}_{2} \mathrm{O}\right.$ and $5 \cdot \mathrm{Bu}_{4} \mathrm{NOAc} \cdot 3 \mathrm{H}_{2} \mathrm{O}$ ). Complexes $\mathbf{1} \cdot \mathrm{Bu}_{4} \mathrm{NH}_{2} \mathrm{PO}_{4}$ and $\mathbf{3} \cdot \mathrm{Bu}_{4} \mathrm{NH}_{2} \mathrm{PO}_{4}$ were formed in $\mathrm{DMF}$, the solvent was evaporated and the residue dissolved in $\mathrm{CH}_{2} \mathrm{Cl}_{2}$ to furnish single-crystals suitable for the measurements after evaporation. The measurements were performed on an Oxford Diffraction Xcalibur Nova $\mathrm{R}$ diffractometer with a microfocus $\mathrm{Cu}$-tube using graphite-monocromated $\mathrm{CuK} \alpha$ radiation $(\lambda$ $=1.54179 \AA$ ). . Program package CrysAlis $\mathrm{PRO}^{44}$ was used for data reduction and multi-scan absorption correction. The sample of $\mathbf{1} \cdot \mathrm{Bu}_{4} \mathrm{NH}_{2} \mathrm{PO}_{4}$ was measured on a three-cycle MD-2 Micro Diffractometer at the European Synchrotron Radiation Facility (ESRF, beamline BM-14), Grenoble, France. Due to the small size of the crystals and large unit cells, comprising only light atoms (Table in the supporting info.), the data for $\mathbf{3} \cdot \mathrm{Bu}_{4} \mathrm{NH}_{2} \mathrm{PO}_{4}$ and $\mathbf{1} \cdot \mathrm{Bu}_{4} \mathrm{NH}_{2} \mathrm{PO}_{4}$ were of inferior quality. The structures were solved using SHELXS97 $7^{45}$ and refined with SHELXL97. ${ }^{45}$ The structures $\mathbf{2}$ and $\mathbf{1}$ were refined using the full-matrix least squares refinement; all non-hydrogen atoms were refined anisotropically. Due to poor data and large number of parameters, $\mathbf{3} \cdot \mathrm{Bu}_{4} \mathrm{NH}_{2} \mathrm{PO}_{4}$ and $\mathbf{1} \cdot \mathrm{Bu}_{4} \mathrm{NH}_{2} \mathrm{PO}_{4}$ were refined using severe geometric restraints and some atoms in tetrabutylammonium moieties were refined isotropically. While full-matrix least-squares refinement was possible for $\mathbf{2} \cdot \mathrm{Bu}_{4} \mathrm{NH}_{2} \mathrm{PO}_{4}$, the number of parameters in $\mathbf{1} \cdot \mathrm{Bu}_{4} \mathrm{NH}_{2} \mathrm{PO}_{4}$ exceeded the capacity of SHELXL-97, ${ }^{45}$ and was therefore refined using a block-diagonal matrix. Hydrogen atoms in $\mathbf{1}, \mathbf{1} \cdot \mathrm{Bu}_{4} \mathrm{NH}_{2} \mathrm{PO}_{4}$ and $\mathbf{2} \cdot \mathrm{Bu}_{4} \mathrm{NH}_{2} \mathrm{PO}_{4}$ were treated as constrained entities, using the command AFIX in SHELXL97; ${ }^{45}$ in 2 they were located from difference Fourier map and refined as free isotropic entities. In $\mathbf{5} \cdot \mathrm{Bu}_{4} \mathrm{NH}_{2} \mathrm{PO}_{4} \cdot 4 \mathrm{H}_{2} \mathrm{O}$ and $\mathbf{5} \cdot \mathrm{Bu}_{4} \mathrm{NOAc} \cdot 3 \mathrm{H}_{2} \mathrm{O}$ hydrogen atoms bound to $\mathrm{C}$ atoms were treated as constrained entities, while those bound to water oxygens were located from difference Fourier map and refined with geomertic restraints $[d(\mathrm{O}-\mathrm{H})=0.95(2) \AA ; d(\mathrm{H} \cdots \mathrm{H})=1.50(4) \AA]$. Molecular geometry calculations were performed by PLATON, ${ }^{46}$ and molecular graphics were prepared using ORTEP- $3,{ }^{47}$ and CCDC-Mercury. ${ }^{48}$ Crystallographic and refinement data for the structures reported in this paper are shown in table in the supporting info (Table S3).

\section{Acknowledgments}

The financing from the Ministry of Science, Education and Sports of the Republic of Croatia (grants no. 098-0982933-2911; 098-1191344-2943) is gratefully acknowledged. The authors thank Prof. M. J. Hynes for the EQNMR program, Mr. Ž. Marinić for recording NMR 
spectra, Prof. V. Tomišić for the use of UV-vis spectrometer, J. Alešković for the help to apply the SPECFIT program and N. Bregovic for the critical reading of the manuscript. The crystallographic measurement of $\mathbf{1} \cdot \mathrm{Bu}_{4} \mathrm{NH}_{2} \mathrm{PO}_{4}$ was performed on the BM14 beamline at the European Synchrotron Radiation Facility (ESRF), Grenoble, France. We are grateful to Dr. Hassan Berlhali at ESRF for providing assistance in using beamline BM14.

\section{References and notes}

1. a) Supramolecular Chemistry of Anions; Bianchi, A.; Bowman-James, K.; Garcia-España, E., Eds.; VCH Verlag: Weinheim, 1997. b) Anion receptor chemistry; Sessler, J.L.; Gale, P.A.; Cho, W.-S., Eds.; RSC publishing: Cambridge, 2006.

2. a) Schmidtchen, F.P.; Berger, M. Chem. Rev. 1997, 97, 1609-1646. b) Beer, P.D.; Gale, P.A. Angew. Chem. Int. Ed. 2001, 40, 486-516. c) Sessler, J.L.; Davis, J.M. Acc. Chem. Res. 2001, 34, 989-997. d) Martínez-Máñez, R.; Sancenón, F. Chem. Rev. 2003, 103, 44194476. e) Gale, P.A. Chem. Commun. 2005, 3761-3772. f) Kang, S.O.; Begum, R.A.; Bowman-James, K. Angew. Chem. Int. Ed. 2006, 45, 7882-7894. g) Gale, P.A. Acc. Chem. Res. 2006, 39, 465-475. h) Caltagirone, C.; Gale, P.A. Chem. Soc. Rev. 2009, 38, 520-563. i) Gale, P.A. Chem. Soc. Rev. 2010, 39, 3746-3771. j) Wenzel, M.; Hiscock, J.R.; Gale, P.A. Chem. Soc. Rev. 2012, 41, 480-520.

3. a) Schmidtchen, F.P. Top. Curr. Chem. 2005, 255, 1-29. b) Bowman-James, K. Acc. Chem. Res. 2005, 38, 671-678. c) Schmidtchen, F.P. Coord. Chem. Rev. 2006, 250, 2918-2928. d) Amendola, V.; Bonizzoni, M.; Estebán-Gómez, D.; Fabbrizzi, L.; Licchelli, M.; Sancenón, F.; Taglietti, A. Coord. Chem. Rev. 2006, 250, 1451-1470.

4. Hay, B.P. Chem. Soc. Rev. 2010, 39, 3700-3708.

5. a) García-España, E.; Díaz, P.; Llinarez, J.M.; Bianchi, A. Coord. Chem. Rev. 2006, 250, 2952-2986. b) Schmuck, C. Coord. Chem. Rev. 2006, 250, 3053-3067. c) Rehm, T.H.; Schmuck, C. Chem. Soc. Rev. 2010, 39, 3597-3611. d) Kubik, S. Chem. Soc. Rev. 2010, 39, 3648-3663.

6. a) Davis, A.P. Coord. Chem. Rev. 2006, 250, 2939-2951. b) Brotherhood, P.R.; Davis, A.P. Chem. Soc. Rev. 2010, 39, 3633-3647. c) Davis, J.T.; Okunola, O.; Quesada, R. Chem. Soc. Rev. 2010, 39, 3843-3862. d) Davis, J.T. Top. Heterocycl. Chem. 2010, 24, 145-176. e) Gale, P.A. Acc. Chem. Res. 2011, 44, 216-226. 
7. a) Aakeröy, C.B.; Seddon, K.R. Chem. Soc. Rev. 1993, 22, 397-407. b) Hosseini, M.W. Coord. Chem. Rev. 2003, 240, 157-166. c) Custelcean, R. Chem. Commun. 2008, 295-307. d) Custelcean, R. Chem. Soc. Rev. 2010, 39, 3675-3685.

8. a) de Silva, A.P.; Gunaratne, H.Q.N.; Gunnlaugsson, T.; Huxley, A.J.M.; McCoy, C.P.; Rademacher, J.T.; Rice, T.E. Chem. Rev. 1997, 97, 1515-1566. b) Suksai, C.; Tuntulani, T. Top. Curr. Chem. 2005, 255, 163-198. c) Gunnlaugsson, T.; Glynn, M.; Tocci, G.M.; Kruger, P.E.; Pfeffer, F.M. Coord. Chem. Rev. 2006, 250, 3094-3117. d) Nguyen, B.T.; Anslyn, E.V. Coord. Chem. Rev. 2006, 250, 3118-3127.

9. a) Bühlmann, P.; Pretsch, E.; Bakker, E. Chem. Rev. 1998, 98, 1593-1687.b) Davis, F.; Collyer, S.D.; Higson, S.P.J. Top. Curr. Chem. 2005, 255, 97-124.

10. Anzenbacher, P. Jr.; Lubal, P.; Buček, P.; Palacios, M.A.; Kozelkova, M.E. Chem. Soc. Rev. 2010, 39, 3954-3979.

11. Hay, B.P.; Firman, T.K. Inorg. Chem. 2002, 41, 5502-5512.

12. a) Li, A.-F.; Wang, J.-H.; Wang, F.; Jiang, Y.-B., Chem. Soc. Rev. 2010, 39, 3729-3745.

b) Amendola, V.; Fabbrizzi, L.; Mosca, L. Chem. Soc. Rev. 2010, 39, 3889-3915. c) Volz, N.; Clayden, J. Angew. Chem. Int. Ed. 2011, 50, 12148-12155.

13. Choi, K.; Hamilton, A.D. Coord. Chem. Rev. 2003, 240, 101-110.

14. Bryantsev, V.S.; Hay, B.P. J. Am. Chem. Soc. 2006, 128, 2035-2042.

15. Blažek, V.; Bregović, N.; Mlinarić-Majerski, K.; Basarić, N. Tetrahedron, 2011, 67, 38463857.

16. In the notation of the receptor:anion complexes throughout the manuscript the counterion (tetrabutylammonium) is often omitted due to simplicity.

17. Keizer, H.M.; González, J.J.; Segura, M.; Prados, P.; Sijbesma, R.P.; Meijer, E.W.; de Mendoza, J. Chem. Eur. J. 2005, 11, 4602-4608.

18. Blažek, V.; Basarić, N.; Majerski, K., HR Patent P20090186A, 2009.

19. Smith, G.W.; Williams, H.D., US Patent 3053907, 1958.

20. Blažek, V.; Qin, W.; Mlinarić-Majerski, K.; Basarić, N. J. Photochem. Photobiol. A: Chem. 2012, 229, 1-10.

21. Lee, J.Y.; Cho, E.J.; Mukamel, S.; Nam, K.C. J. Org. Chem. 2004, 69, 943-950.

22. a) Grampp, H.; Maeder, M.; Meyer, C.J.; Zuberbühler, A.D. Talanta 1985, 32, 95-101. b) Grampp, H.; Maeder, M.; Meyer, C.J.; Zuberbühler, A.D. Talanta 1985, 32, 257-264. c) Grampp, H.; Maeder, M.; Meyer, C.J.; Zuberbühler, A.D. Talanta 1985, 32, 1133-1139. 
23. a) Gunnlaugsson, T.; Kruger, P.E.; Lee, T.C.; Parkesh, R.; Pfeffer, F.M.; Hussey, G.M. Tetrahedron Lett. 2003, 44, 6575-6578. b) Gunnlaugsson, T.; Kruger, P.E.; Jensen, P.; Pfeffer, F.M.; Hussey, G.M. Tetrahedron Lett. 2003, 44, 8909-8913. c) Camiolo, S.; Gale, P.A.; Hursthouse, M.B.; Light, M.E. Org. Biomol. Chem. 2003, 1, 741-744. d) Boiocchi, M.; Del Boca, L.; Gómez, D.E.; Fabbrizzi, L.; Licchelli, M.; Monzani, E. J. Am. Chem. Soc. 2004, 126, 16507-16514. e) Boiocchi, M.; Del Boca, L.; Esteban-Gómez, D.; Fabbrizzi, L.; Licchelli, M.; Monzani, E. Chem. Eur. J., 2005, 11, 3097-3104. f) Gómez, D.E.; Fabbrizzi, L.; Licchelli, M.; Monzani, E. Org. Biomol. Chem. 2005, 3, 1495-1500. g) Amendola, V.; Esteban-Gómez, D.; Fabbrizzi, L.; Licchelli, M. Acc. Chem. Res. 2006, $39,343-353$.

24. Steiner, T. Angew. Chem. Int. Ed. 2002, 41, 48-76.

25. Duke, R.M.; McCabe, T.; Schmitt, W.; Gunnlaugsson, T. J. Org. Chem. 2012, 77, $3115-$ 3126.

26. Ireland, J.F.; Wyatt, P.A.H. Adv. Phys. Org. Chem. 1976, 12, 131-221.

27. Fan, E.; Van Arman, S.A.; Kincaid, S.; Hamilton, A.D. J. Am. Chem. Soc. 1993, 115, 369370.

28. a) Brooks, S.J.; Edwards, P.R.; Gale, P.A.; Light, M.E. New J. Chem. 2006, 30, 65-70. b) Formica, M.; Fusi, V.; Macedi, E.; Paoli, P.; Piersanti, G.; Rossi, P.; Zappia, G.; Orlando, P. New J. Chem. 2008, 32, 1204-1214.

29. Nishizawa, S.; Bühlmann, P.; Iwao, M.; Umezawa, Y. Tetrahedron Lett. 1995, 36, 64836486.

30. Brooks, S.J.; Caltagirone, C.; Cossins, A.J.; Gale, P.A.; Light, M. Supramol. Chem. 2008, 20,349-355.

31. Lowe, A.J.; Dyson, G.A.; Pfeffer, F.M. Org. Biomol. Chem. 2007, 5, 1343-1346.

32. Kim, Y.-J.; Kwak, H.; Lee, S.J.; Lee, J.S.; Kwon, H.J.; Nam, S.H.; Lee, K.; Kim, C. Tetrahedron, 2006, 62, 9635-9649.

33. Hamann, B.C.; Branda, N.R.; Rebek, J.Jr. Tetrahedron Lett. 1993, 34, 6837-6840.

34. a) Hossain, Md.A.; Llinares, J.M.; Powell, D.; Bowman-James, K. Inorg. Chem. 2001, 40, 2936-2937. b) Kang, S.O.; Hossain, Md.A.; Powell, D.; Bowman-James, K. Chem. Commun. 2005, 41, 328-330. c) Custelcean, R.; Moyer, B.A.; Hay, B.P. Chem. Commun. 2005, 41, 5971-5973. d) Jose, D.A.; Kumar, D.K.; Ganguly, B.; Das, A. Inorg. Chem. 2007, 46, 5817-5819. e) Wu, B.; Liang, J.; Yang, J.; Yang, X.-J.; Zhang, H.; Tang, N.; Janiak, C. Chem. Commun. 2008, 44, 1762-1764. f) Custelcean, R.; Bosano, J.; Bonnesen, P.V.; 
Kertesz, V.; Hay, B.P. Angew. Chem. Int. Ed. 2009, 48, 4025-4029. g) Mendy, J.S.; Pilate, M.L.; Horne, T.; Day, V.W.; Hossain, Md.A. Chem. Commun 2010, 46, 6084-6086. h) Pamanik, A.; Thompson, B.; Hayes, T.; Tucker, K.; Powell, D.R.; Bonnesen, P.V.; Ellis, E.D.; Lee, K.S.; Yu, H.; Hossain, Md.A. Org. Biomol. Chem. 2011, 9, 4444-4447.

35. a) Bühlmann, P.; Nishizawa, S.; Xiao, K.P.; Umezawa, Y. Tetrahedron 1997, 53, $1647-$ 1654. b) Kondo, S.-I.; Sato, M. Tetrahedron 2006, 62, 4844-4850. c) Kwon, J.Y.; Jang, Y.J.; Kim, S.K.; Lee, K.-H.; Kim, J.S.; Yoon, J. J. Org. Chem. 2004, 69, 5155-5157. d) Kim, S.K.; Singh, N.J.; Kim, S.J.; Swamy, K.M.K.; Kim, S.H.; Lee, K.-H.; Kim, K.S.; Yoon, J. Tetrahedron 2005, 61, 4545-4550.

36. Amendola, V.; Boiocchi, M.; Esteban-Gómez, D.; Fabbrizzi, L.; Monzani, E. Org. Biomol. Chem. 2005, 3, 2632-2639.

37. Calderon-Kawasaki, K.; Kularatne, S.; Li, Y.H.; Noll, B.C.; Scheidt, W.R.; Burns, D.H. J. Org. Chem. 2007, 72, 9081-9087.

38. a) Etter, M.; MacDonald, J.C.; Bernstein, J. Acta Cryst. B 1990, 46, 256-262. b) Bernstein, J.; Davis, R.E.; Shimoni, L.; Chang, N.-L. Angew. Chem. Int. Ed. 1995, 34, 1555-1573.

39. Piepenbrock, M.-O.M.; Lloyd, G.O.; Clarke, N.; Steed, J.W. Chem. Commun. 2008, 26442646.

40. Allen, F., Acta Cryst. B 2002, 58, 380-388.

41. a) Yin, Z.; Zhang, Y.; He, J.; Cheng, J.-P. Tetrahedron, 2006, 62, 765-770. b) Koralegedara, M.E.; Aw, H.W.; Burns, D.H. J. Org. Chem. 2011, 76, 1930-1933.

42. a) Novikov, S.S.; Hardin, A.P.; Butenko, L.N.; Novakov, I.A.; Radchenko, S.S. Izv. Akad. Nauk. SSSR Ser. Khim. 1976, 2597-2599. b) Stetter, H.; Wulff, C. Chem. Ber., 1960, 93, 1366-1371.

43. Hynes, M.J. J. Chem. Soc., Dalton Trans. 1993, 311-312.

44. CrysAlis PRO, Oxford Diffraction Ltd., U.K., 2007.

45. Sheldrick, G.M. Acta Cryst., 2008, A64, 112-122.

46. Spek, A.L. J. Appl. Cryst., 2003, 36, 7-13.

47. Farugia, L.J. J. Appl. Cryst., 1997, 30, 565.

48. Macrae, C.F.; Edgington, P.R.; McCabe, P.; Pidcock, E.; Shields, G.P.; Taylor, R.; Towler, M.; van de Streek, J. J. Appl. Cryst., 2006, 39, 453-457.

\section{Supplementary Material}


Blažek, V.; Molčanov, K.; Mlinarić-Majerski, K.; Kojić-Prodić, B.; Basarić, N. Adamantane bisurea derivatives: anion binding in the solution and in the solid state. Tetrahedron. 2013, 69, 517-526. DOI: 10.1016/j.tet.2012.11.030 - Accepted Version

Supplementary material contains spectra and fittings obtained by UV-vis, fluorescence and NMR titration. Supplementary crystallographic data for this paper can be obtained free of charge via www.ccdc.cam.ac.uk/conts/retrieving.html (or from the Cambridge Crystallographic Data Centre, 12, Union Road, Cambridge CB2 1EZ, UK; fax: +44 1223 336033; or deposit@ccdc.cam.ac.uk). CCDC 889130 - 889135 contain the supplementary crystallographic data for this paper. 